\title{
Differential proteomic analysis of a human breast tumor and its matched bone metastasis identifies cell membrane and extracellular proteins associated with bone metastasis
}

Bruno Dumont, Vincent Castronovo, Olivier Peulen, Noela Bletard, Philippe Clézardin, Philippe Delvenne, Edwin De Pauw, Andrei Turtoi, and Akeila Bellahcène

J. Proteome Res., Just Accepted Manuscript • DOI: 10.1021/pr201022n • Publication Date (Web): 22 Feb 2012

Downloaded from http://pubs.acs.org on February 29, 2012

\section{Just Accepted}

"Just Accepted" manuscripts have been peer-reviewed and accepted for publication. They are posted online prior to technical editing, formatting for publication and author proofing. The American Chemical Society provides "Just Accepted" as a free service to the research community to expedite the dissemination of scientific material as soon as possible after acceptance. "Just Accepted" manuscripts appear in full in PDF format accompanied by an HTML abstract. "Just Accepted" manuscripts have been fully peer reviewed, but should not be considered the official version of record. They are accessible to all readers and citable by the Digital Object Identifier (DOI®). "Just Accepted" is an optional service offered to authors. Therefore, the "Just Accepted" Web site may not include all articles that will be published in the journal. After a manuscript is technically edited and formatted, it will be removed from the "Just Accepted" Web site and published as an ASAP article. Note that technical editing may introduce minor changes to the manuscript text and/or graphics which could affect content, and all legal disclaimers and ethical guidelines that apply to the journal pertain. ACS cannot be held responsible for errors or consequences arising from the use of information contained in these "Just Accepted" manuscripts. 


\title{
Differential proteomic analysis of a human breast tumor and its matched bone metastasis identifies cell membrane and extracellular proteins associated with bone metastasis
}

\author{
Bruno Dumont ${ }^{1}$, Vincent Castronovo ${ }^{1}$, Olivier Peulen ${ }^{1}$, Noëlla Blétard ${ }^{2}$, Philippe Clézardin $^{3}$, \\ Philippe Delvenne ${ }^{2}$, Edwin A. De Pauw ${ }^{4}$, Andrei Turtoi* ${ }^{1,4}$ and Akeila Bellahcène*1 \\ ${ }^{1}$ Metastasis Research Laboratory, University of Liège, Bat. B23, CHU Sart Tilman Liège, B- \\ 4000 Liège, Belgium \\ ${ }^{2}$ Department of Pathology, University of Liège, Bat. B23, CHU Sart Tilman Liège, B-4000 \\ Liège, Belgium \\ ${ }^{3}$ INSERM, Research Unit 1033, UFR de Médecine Lyon-Est (domaine Laënnec), F-69372 \\ Lyon Cedex 08, France \\ ${ }^{4}$ Laboratory of Mass Spectrometry, Department of Chemistry, University of Liège, Bat. B6c, \\ B-4000 Liège, Belgium \\ *Authors contributed equally to the study
}

Corresponding author:

Akeila Bellahcène, Ph.D.

Metastasis Research Laboratory,

GIGA-Cancer, University of Liege,

Tel. 003243662557

Fax: 003243662975

E-mail: a.bellahcene@ulg.ac.be 


\begin{abstract}
The classical fate of metastasizing breast cancer cells is to seed and form secondary colonies in bones. The molecules closely associated with these processes are predominantly present at the cell surface and in the extracellular space, establishing the first contacts with the target tissue. In this study, we had the rare opportunity to analyze a bone metastatic lesion and its corresponding breast primary tumor obtained simultaneously from the same patient. Using mass spectrometry, we undertook a proteomic study on cell surface and extracellular proteinenriched material. We provide a repertoire of significantly modulated proteins, some with yet unknown roles in the bone metastatic process as well as proteins notably involved in cancer cell invasiveness and in bone metabolism. The comparison of these clinical data with those previously obtained using a human osteotropic breast cancer cell line highlighted an overlapping group of proteins. Certain differentially expressed proteins are validated in the present study using immunohistochemistry on a retrospective collection of breast tumors and matched bone metastases. Our exclusive set of selected proteins supports the set-up of further investigations on both clinical samples and experimental bone metastasis models that will help to reveal the finely coordinated expression of proteins that favor the development of metastases in the bone microenvironment.
\end{abstract}

Keywords: bone metastasis, breast cancer, primary tumor, matched, proteomics

Abbreviations: BM: bone metastasis; GSSG: oxidized glutathione; PT: primary tumor; SLRP: small leucine-rich proteoglycan 


\section{INTRODUCTION}

Some of the most frequently occurring cancers, including breast, lung, and prostate adenocarcinomas, predictably metastasize to bone. In the United States, bone metastases affect more than 400000 people every year. For advanced breast tumors, 70\% of patients will develop metastasis into the skeleton. ${ }^{1}$ Although there has been progress in the treatment of breast cancer, the prognosis of patients is still limited by the occurrence of distant metastases. Clinically, bone metastases are often associated with high morbidity, including hypercalcemia, pathological fracture, spinal cord compression, and severe bone pain. Bisphosphonates are a class of pharmacological agents that inhibit osteoclast-mediated bone resorption and hence can prevent the morbidity associated with skeletal lesions. ${ }^{2}$

At the biological level, cancer cells within the tumor mass have to adapt to a particular microenvironment. For metastases to occur, cancer cells must adjust their phenotype to survive and grow in their new seeding site. Thus, they must survive in the circulation, seed in the target organ, extravasate into it, and show persistent growth. ${ }^{3}$ It is therefore important to identify the molecular mediators that support the settling of cancer cells in distant organs. ${ }^{4-6}$

Because it is difficult to obtain suitable clinical specimens, studies on primary tumors and their matched metastases are rare. ${ }^{7}$ An obvious reason is that primary breast tumors are usually surgically removed before the occurrence of metastases. This is particularly true for breast cancer for which macroscopic metastases may erupt many years after the primary tumor resection. ${ }^{8}$ Moreover, the metastases are not removed at all when the disease is well advanced. In addition, removed metastases are generally small and must be processed intact for pathology to confirm their metastatic identity, leaving no samples for research.

In breast cancer research, gene expression profiles of matched metastases and primary tumors from clinical specimens are understudied. Indeed, the few published studies reporting differential gene expression used primary tumor and associated lymph node metastases 
samples. ${ }^{7}$ The lack of studies on human metastatic specimens is particularly apparent when it comes to characterizing the main changes associated with tumor cell dissemination at the protein level. ${ }^{5,6}$ There have been only two original reports describing differential protein expression on clinical specimens. These proteomic studies compared primary breast tumors and matched regional lymph node metastases. ${ }^{9,}{ }^{10}$ In the context of breast cancer metastasis, most of the studies were performed with human cancer cell lines having different metastatic potencies. ${ }^{11,12}$ Our group has been involved in several studies aimed at understanding the molecular mechanisms driving tumor cells to metastasize. Due to the limitations described above, we have used a transcriptomic approach to identify differentially expressed genes between MDA-MB-231 human breast cancer cells and their bone metastasis-derived isogenic clone called B02. ${ }^{13}$ More recently, we completed this study using a cell membrane proteomic analysis on the same material. ${ }^{14}$ So far, no proteomic comparative study on primary breast cancer and its matched bone metastases has been reported. In the present work, we had the rare opportunity to collect and investigate a primary breast tumor and its matched bone metastase collected from a patient at autopsy.

Cell surface and extracellular matrix proteins are the first interface in the complex dialogue between the tumor and its microenvironment that occurs upon metastatic dissemination. Proteomic approaches are able to identify and quantify this subset of proteins with specific cellular localization. However, the extensive dynamic range of the entire cellular proteome precludes a straightforward proteomic analysis. Therefore, we employed a specific and comprehensive three-step approach to enrich cell surface and extracellular proteins. ${ }^{15}$ First, the cell surface proteins were labeled in intact tissue samples with modified biotin and extracted using affinity chromatography. Second, from the remaining material a selective enrichment of glycopeptides was performed to identify glycoproteins that are known to be preferentially secreted or membrane based. The last step involved analysis of the remaining 
peptides, which were neither biotinylated nor glycosylated, covering comprehensively an additional spectrum of secreted and membrane proteins.

The results reported here provide a pattern of differentially expressed proteins in the primary breast tumor versus the associated bone metastasis. Selected proteins identified in the proteomic analysis were further validated in a collection of breast tumor and matched bone metastasis samples employing immunohistochemistry. The comparison of the proteomic data with those previously obtained using the cell line models indicated an overlap for several proteins. However, most of the newly identified proteins were not previously reported in our cell-based study. The roles of some of these proteins remain unknown in the metastatic process. Others have been previously implicated in the migration and invasion of cancer cells. Interestingly, a number of proteins taking part either in bone mineralization or destruction were noticeable consistent with our $^{13}$, and others ${ }^{16,17}$, description of an osteoblast-like phenotype acquired by bone metastatic cells.

The current study identifies novel proteins potentially implicated in the important cross talk between the cancer cells and their microenvironment. This process may be a significant factor to the development of bone metastases. The identification of differentially expressed proteins between the primary breast tumor and its matched bone metastasis opens the possibility for further functional studies and features as a platform for the discovery of new biomarkers potentially useful in diagnostic and therapeutic applications. 


\section{MATERIALS AND METHODS}

\section{Patient}

The patient was diagnosed with breast cancer in 1986 at the age of 57 and underwent a tumorectomy. After surgery, she was treated by a classical radiotherapy and chemotherapy regimen. Adjuvant tamoxifen therapy was also administered. In December 2005, the patient was admitted for a worsening in her general status and aggravation of an anterior epileptic illness. One month later, she died from disseminated metastatic disease. An autopsy performed within 8 hours revealed a breast tumor relapse and metastases in bone, liver, and adrenal glands.

The sample derived from the newly developed (2005) breast tumor and its associated bone metastasis were simultaneously obtained at autopsy through the Department of Pathology (Centre Hospitalier Universitaire of Liège, Belgium). The Ethics Committee of the University Hospital of Liège reviewed and approved the protocol used in this study.

Single nucleotide polymorphism analysis of the primary breast tumor and its matched bone metastasis

To confirm the clonal relationship between the breast tumor and the matched bone metastasis, whole genome screening for single nucleotide polymorphism (SNP) was performed. Additionally, one non-related case of breast tumor was also analyzed. Frozen tissues were transformed into powder using a Mikro-Dismembrator U (Braun Biotech, Melsungen, Germany). DNA was extracted and purified with the Maxwell 16 Tissue DNA Purification kit (Promega, Madison, WI, USA) as described in the manufacturer's instruction. Isolated DNA (750 ng) was amplified, fragmented, and hybridized on the BeadChip HumanOmni 2.5-4 V1 using Infinium ${ }^{\circledR}$ II Assay Workflow (Illumina, San Diego, CA, USA). Data were accrued using the iSCAN scanner (Illumina) and the results were processed with the GenomeStudio software (module Genotyping; Illumina) (Figure S1, Supplemental Data). 
The correlation analysis between different samples was performed using Pearson correlation of allele frequency (Excel, Microsoft, Redmond, WA, USA).

\section{Isolation of cell surface and extracellular proteins}

Upon sampling, the primary tumor and the paired bone metastatic lesion were processed as previously described. ${ }^{18}$ Briefly, the tissues were sliced, washed with PBS (Invitrogen, Carlsbad, CA, USA), and soaked in freshly prepared sulfosuccinimidyl-2 (biotinamido) ethyl-1,3-dithiopropionate (1 mg/ml EZ-link sulfo-NHS-SS-biotin; Pierce, Thermo Scientific, Rockford, IL, USA) in PBS ( $\mathrm{pH} \mathrm{7.4)^{19 }}$, except for a tiny portion of each sample that was directly immersed in formalin and then processed for further histological and histochemical investigations. The biotinylation reaction was quenched following $5 \mathrm{~min}$ incubation in $50 \mathrm{mM}$ Tris PBS (pH 7.4).

Protein isolation was performed as previously described ${ }^{15}$ with slight modifications. Tissues were pulverized using a Mikro-Dismembrator U. Approximately $100 \mathrm{mg}$ of tissue powder was first dispersed in a PBS buffer containing $0.5 \mathrm{M} \mathrm{NaCl}$, protease inhibitor cocktail (Halt ${ }^{\mathrm{TM}}$, Pierce), and $0.5 \mathrm{mM}$ of oxidized glutathione (GSSG) (Sigma Aldrich, St. Louis, MO, USA). Homogenates were sonicated ( 2 x $30 \mathrm{~s})$ with a $2 \mathrm{~mm}$ microprobe and soluble proteins were subjected to human serum albumin (HSA) and immunoglobulin (IgGs) depletion (Qproteome HSA and IgGs Removal Kit, Quiagen, Hilden, Germany). The insoluble pellet was then dissolved in RIPA buffer (1\% NP-40, 0.5\% DOC, 0.1\% SDS, $0.5 \mathrm{M} \mathrm{NaCl}, 0.5 \mathrm{mM}$ GSSG, and PI cocktail in PBS, pH 7.0), and lysates were sonicated ( 2 x 30 s), centrifuged, and further depleted in HSA and IgGs. The insoluble pellet was finally dissolved in 2\% SDS. HSA- and IgGs-depleted proteins fraction and SDS-solubilized proteins were pooled and boiled for $5 \mathrm{~min}$.

Isolation of biotinylated proteins: High capacity streptavidin-agarose beads (100 $\mu 1$ of slurry/mg of total proteins; Pierce) were preconditioned in buffer A (1\% NP-40, 0.1\% SDS, 
$0.5 \mathrm{M} \mathrm{NaCl}$ and $0.5 \mathrm{mM} \mathrm{GSSG}$ in PBS) and biotinylated proteins were bound for $2 \mathrm{~h}$ at room temperature in a rotating mixer. The beads were transferred to spin columns (Pierce), centrifuged briefly (the flow-through was collected for the glycopeptide analysis), and the resin was subjected to several wash steps: twice with buffer A, twice with buffer B $(0.1 \%$ NP40, $1.5 \mathrm{M} \mathrm{NaCl}, 0.5 \mathrm{mM}$ GSSG in PBS), twice with buffer C (0.1 M sodium carbonate, $0.5 \mathrm{M}$ $\mathrm{NaCl}$, and $0.5 \mathrm{mM}$ GSSG in PBS, pH 11), and once with PBS (containing $0.5 \mathrm{M} \mathrm{NaCl}$ ). The flow-through from the first two washes was also collected for glycopeptide analysis. Biotinylated proteins were then eluted from the resin by two 30 min incubation steps in $1 \%$ SDS and $100 \mathrm{mM}$ DTT (Sigma Aldrich) in PBS, pH 7.0, at $60^{\circ} \mathrm{C}$ and subsequently alkylated with iodoacetamide (Sigma Aldrich) for $30 \mathrm{~min}$ in the dark. Biotinylated protein fraction was then precipitated overnight with $20 \%$ trichloroacetic acid and washed twice with cold acetone $\left(-20^{\circ} \mathrm{C}\right)$. The pellet was dissolved in $50 \mathrm{mM} \mathrm{NH}_{4} \mathrm{HCO}_{3}, \mathrm{pH} 8.0$, and further digested with trypsin (1:50 trypsin:protein ratio; Promega) overnight at $37^{\circ} \mathrm{C}$. Before mass spectrometry analysis, samples were purified using C18 ZipTip (Millipore, Billerica, MA, USA).

Isolation of glycosylated peptides: Flow-through fractions obtained from the streptavidin-unbound proteins, were pooled, precipitated, and digested overnight (as above). The samples were acidified with $30 \mu \mathrm{L}$ of $1 \% \mathrm{HCl}$ and purified using the $\mathrm{C} 18$ Sep-Pak column (Waters Corporation, Milford, MA, USA). For this purpose, the columns were washed three times with $1 \mathrm{ml}$ of $0.1 \%$ formic acid solution and loaded with the acidified sample. The peptides were then eluted using $80 \%$ acetonitrile and subsequently dried under vacuum. Following this, the samples were oxidized in $50 \mu \mathrm{l}$ of $100 \mathrm{mM}$ sodium acetate buffer containing $150 \mathrm{mM} \mathrm{NaCl}$ and $10 \mathrm{mM}$ sodium periodate, $\mathrm{pH} 5.5$ (Pierce), for $1 \mathrm{~h}$ in the dark. The reaction was quenched with $10 \mu \mathrm{l}$ of $100 \mathrm{mM}$ sodium sulfite (final concentration of 20 $\mathrm{mM}$ ) for $10 \mathrm{~min}$ at room temperature (RT). The samples were then loaded on hydrazide resin (Bio-Rad, Hercules, CA, USA) and the binding of the oxidized glycans to the beads was done 
overnight at RT. Following the incubation, the unbound peptides supernatants were collected for the subsequent mass spectrometry (MS) analysis (rest fraction). After two washing steps with $\mathrm{H}_{2} \mathrm{O}, 1.5 \mathrm{M} \mathrm{NaCl}$, methanol, $80 \% \mathrm{ACN}$, and $50 \mathrm{mM} \mathrm{NH}_{4} \mathrm{HCO}_{3}$, the hydrazide resin was resuspended in $50 \mathrm{mM} \mathrm{NH}_{4} \mathrm{HCO}_{3}$ and incubated overnight with 500 units of PNGase $\mathrm{F}$ (New England Biolabs, Ipswich, MA, USA) at $37^{\circ} \mathrm{C}$. This step enzymatically deglycosylated the Nglycopeptides and released these from the hydrazide beads. The supernatants were collected, dried, dissolved in water containing $2 \%$ acetonitrile and $0.1 \%$ formic acid, and purified using ZipTip before mass spectrometry analysis.

\section{Mass spectrometry}

Peptide samples were loaded on a 2D-nano-HPLC system UltiMate $3000^{\circledR}$ (Dionex, Sunnyvale, CA, USA). The HPLC system was connected online with an electro spray ion-trap mass spectrometer Esquire HCT ultra ${ }^{\circledR}$ (Bruker Daltonics, Bremen, Germany). For the MS analysis, the digested protein sample $(5 \mu \mathrm{g}$ in $25 \mu \mathrm{l}$ at $0.25 \mu \mathrm{g} / \mu \mathrm{l} 2 \%$ acetonitrile and $0.1 \%$ formic acid) was loaded on the Bio-X-SCX column (500 $\mu$ m internal diameter (i.d.) x $15 \mathrm{~mm}$; Dionex, p/n: 161395). Subsequently, four different concentrations of salt injections were performed $(45,75,150$, and $500 \mathrm{mM}$ ammonium acetate). After each salt injection, the eluted peptides from the SCX column were trapped on a C18 pre-column (Acclaim PepMap ${ }^{\odot}, 300$ $\mu \mathrm{m}$ i.d. x $5 \mathrm{~mm}$; Dionex, p/n: 160454) and desalted for $5 \mathrm{~min}$ at a flow rate of $30 \mu \mathrm{L} / \mathrm{min}$ using solvent A (97.9\% water, $2 \%$ acetonitrile, and $0.1 \%$ formic acid). Following this, separation of the peptides was conducted on the C18 analytical column (Acclaim ${ }^{\circledR} 75 \mu$ m i.d. x $150 \mathrm{~mm}$; Dionex, p/n: 162224) using a 120 min solvent gradient $[\mathrm{t}=0 \mathrm{~min}, 0 \% \mathrm{~B}(\mathrm{~B}: 80 \%$ acetonitrile, $19.9 \%$ water, and $0.1 \%$ formic acid); $\mathrm{t}=120 \mathrm{~min}, 40 \% \mathrm{~B}$ ] at a flow rate of 0.3 $\mu \mathrm{L} / \mathrm{min}$. A mass range from 200 to $1600 \mathrm{~m} / \mathrm{z}$ was used. The four most intensive peptides found in this range (bearing +2 and +3 charges) were automatically selected and further fragmented in the MS/MS mode ( $\mathrm{m} / \mathrm{z}$ range 100-2500). 
Raw spectra were deconvoluted using Data Analysis ${ }^{\circledR}$ software (Bruker Daltonics). Proteins were identified using the minimally redundant Swiss-Prot human protein database ${ }^{20}$ (version 57.7 with 20,405 entries) and the MS/MS ion search algorithm of the MASCOT search engine (Daemon v2.2). ${ }^{21}$ Mass tolerances of the precursor and fragmented ions were respectively set at 0.6 and 0.3 . Allowed modifications were partial oxidization (M) and fixed carbamidomethylation (C). One missed cut was allowed. Multidimensional protein identification technology (MudPIT) scoring was employed and ions score cut-off was set to 30. By setting the threshold to this value, all of the low scoring matches (i.e. random peptide matches) were cut out, and homologous proteins were more likely to collapse into a single hit. Furthermore, the absolute probability $(P)$ was set to 0.01 (i.e. less than $1 \%$ probability of a random match). In addition, protein hits were manually inspected one by one.

To estimate the relative protein contents we used the protein abundance index (PAI), which has been demonstrated to be proportional to the absolute protein amount in a complex mixture. ${ }^{22}$ The normalization was conducted assuming the Gaussian distribution of the data, where the maximum number of proteins has a relative quantification ratio (bone metastasis versus primary tumor) of 1 (Figure S2, Supplemental Data).

Regarding the glycoproteins, the processed MS data (deconvoluted spectra) were submitted to the database search (Mascot ${ }^{\circ} /$ Swissprot $\left.{ }^{\circledR}\right)$, first separately for the fraction obtained from the hydrazide beads and then combined with the flow-through fraction. Following this, all the glycoproteins originating from the hydrazide beads were filtered out with a homemade program. This program checked for the presence of deamidated asparagines at the consensus sequence site $(\mathrm{NXS} / \mathrm{T}$, where $\mathrm{X}$ can be replaced by any amino acid except proline) for each of the peptides in question. In this initial step, a certain number of glycopeptides could immediately be assigned to a respective glycoprotein (glycosylated fraction). The remaining glycopeptides were not specific enough or had a relatively low score 
so they could not be unambiguously associated with a protein. In order to help assign these peptides to a protein, they were matched with the peptides from the rest fraction analysis where several non-glycosylated peptides in conjunction with the glycosylated peptides (from the glycosylated fraction) permitted significant protein identification. ${ }^{15}$ The sequence, mass $\mathrm{m} / \mathrm{z}$ value, ion charge, and score of the identified glycopeptides from the differentially expressed glycoproteins are given as Supplemental Data in Table S1.

\section{Immunohistochemistry}

For validation of the selected biomarkers, samples (paraffin-embedded tissues) were selected from the patient used for the proteomic analysis and from 9 additional patients for whom primary breast cancer and matched bone metastasis were available. Cell pellet paraffin blocks of the primary breast cancer MDA-MB-231 cell line and its osteotropic B02 subclone ${ }^{23}$ were also used for validation steps. Paraffin-embedded tissue blocks were sectioned at $5 \mu \mathrm{m}$ thickness. Preceding the immunohistochemistry analysis, bone specimens were decalcified either with a solution of ethylenediaminetetraacetic acid (EDTA) and hydrochloric acid (Decalcifier II, Labonord, Waregem, Belgium) or with a solution of formalin (20\%) and nitric acid (5\%). All the antibodies used (anti-ASPN, SUSD2, CD166, KTN1) were Prestige Antibodies ${ }^{\circledR}$ purchased from Sigma-Aldrich. The secondary antibody was a biotinylated antirabbit antibody (ABC kit; Vector Laboratories, Burlingame, CA, USA). The staining was performed with diaminobenzidine tetrahydrochloride (DAB) substrate (Sigma-Aldrich). Finally, the sections were counterstained with Mayer's hematoxylin.

\section{Immunostaining scoring and statistical analysis}

Scoring of the staining intensity was performed by two independent observers according to a semi-quantitative arbitrary scale of $0,+1,+2$, and +3 , where 0 was considered as undetectable staining in the cancerous cells, +1 as weak positive, +2 as moderate positive, and +3 as highly positive staining. The scores obtained for each breast primary tumor mass 
(PT) were subtracted from the score of the matched bone metastatic lesion (BM) to give the $\Delta$ score. Scores are detailed in Table S2. Results were expressed as $\Delta$ score means \pm standard error of means (Figure 3). The mean values of the $\Delta$ score were compared to the theoretical value of 0 employing a one-sample t-test. Gaussian distribution of the data was assayed by the d'Agostino-Pearson normality test. Following the rationale that the result of the IHC was predicted by the MS analysis, we used a one-tailed t-test where $\mathrm{p}<0.05$ was considered as statistically significant.

\section{Western Blot}

The modulation of protein expression in breast cancer cell lines of Sushi domaincontaining protein 2 (SUSD2) was validated using Western blot technique. A total of $20 \mu \mathrm{g}$ total protein extracts were separated on a sodium dodecyl sulfate-polyacrylamide gel electrophoresis (SDS-PAGE) under reducing conditions. Proteins were transferred to nitrocellulose membranes (Bio-Rad) at $30 \mathrm{~V}$ overnight at $4{ }^{\circ} \mathrm{C}$. Following the transfer, the membranes were blocked for $2 \mathrm{~h}$ at RT with $5 \%$ milk (Bio-Rad). The membrane was incubated for $2 \mathrm{~h}$ at RT with rabbit anti-SUSD2 (dilution 1/500 - Sigma-Aldrich) antibody. Following the incubation with the HRP-conjugated anti-rabbit (Invitrogen) secondary antibody, the membrane was washed with TBS-T $0.05 \%$ and then developed using ECL substrate (Pierce). HSC70 protein was used for normalization purposes. 


\section{RESULTS AND DISCUSSION}

\section{Identification of differentially expressed proteins in the primary breast tumor and its} matched bone metastasis

We had the unique opportunity to analyze a primary breast tumor and its matched bone metastatic lesion that were collected simultaneously at the time of autopsy. This study was focused on the identification of differentially expressed proteins localized at the cell membrane and in the extracellular space. For this purpose, tissue material was processed in quadruplicate for the "biotinylated" fraction, duplicate for the "glycosylated" fraction, and duplicate for the "rest" protein fraction (Figure 1). The proteins were identified using the human Swissprot ${ }^{\circledR}$ database and their subcellular localizations were annotated according to Uniprot $^{\circledR}$ Gene Ontologies. In breast tumor and bone metastasis specimens, each fraction contributed to a certain number of membrane and extracellular matrix proteins (Figure 2A) with the glycosylated fractions expectedly providing the most important proportion of membrane and extracellular matrix proteins. In comparison to each other, fractions displayed some overlap in protein identification, but a significant portion of proteins was unique to each fraction (Figure 2B). As we have previously demonstrated, in comparison to any individual fraction, the sequential method significantly increases the number of identified cell surface and extracellular proteins. ${ }^{15}$

Following the identification of membrane and extracellular matrix proteins, a comparative analysis between the primary tumor and the bone metastasis was performed. According to the emPAI based relative quantification, the median ratio of the different fractions was approximately equivalent to 1 (Figure S2, Supplemental Data). Consequently, no normalization was required to assess the relative quantification of the modulated proteins. Altogether, a protein was considered as differentially expressed based primarily on its presence or absence in all technical replicates. When one protein was equally present in both 
conditions, the exponentially modified protein abundance index (emPAI) was used as a semiquantitative value. ${ }^{22}$ Hence, a protein was considered as differentially expressed when (i) it was detected in one clinical specimen type but not in the other, (ii) it was found in both specimens but preferentially expressed in one of these two specimens or (iii) it was found equally present in both specimens, but with a calculated emPAI value of at least 4 times greater in one condition than in the other. When a protein was identified in more than one fraction ("biotinylated", "glycosylated", and/or "rest") and displayed an opposite modulation, it was considered as non-differentially expressed. Based on these criteria, 354 (85\%) proteins were considered to be non-modulated, whereas $63(15 \%)$ proteins were found differentially expressed (Figure S3). Because of the uniqueness of the clinical material and the membrane proteomic technique used in this study, there is no available data in the literature to serve as a direct comparison. Earlier microarray studies comparing primary tumors and metastatic samples from breast cancer patients have also pointed to the close resemblance of gene expression patterns of clinical primary tumors and their metastases. ${ }^{24-26}$ Gene expression profiling of human lymph node metastases and matched primary breast carcinomas also showed that metastases resemble their primary tumors. ${ }^{7}$ Recently, Klein et al. performed a transcriptomic study comparing primary tumors to their metastases and reported that primary tumors relapsing to bone share similar expression profiles with bone metastases while they do not cluster together with the brain metastases examined in the same study. ${ }^{27}$ Concerning the identified proteins/genes, no similarity was observed between the current study and that of Klein et al. However, the latter identified 22 bone specific genes, where the majority was implicated in the cell migration and extracellular matrix remodeling, suggesting a role in the formation of a specific tumor microenvironment. Although there was no overlap in terms of identity of modulated protein/genes between the current proteomic study and the previous 
genomic investigation, the function and the biological role of highlighted protein/genes is similar.

Although the primary breast tumor and the cognate bone metastasis do not display major genetic differences, ${ }^{7,24-27}$ we were still able to identify a substantial number of membrane and extracellular matrix proteins that were differentially expressed, among which $34(54 \%)$ proteins were found down-regulated whereas $29(46 \%)$ proteins were up-regulated in the bone metastasis (Figure S3, Tables 1 and 2). A survey of the existing literature related to these 63 differentially expressed proteins identify important processes linked to tumor progression and bone metastasis development (Table 3A and B). Values of the score, number of unique peptides and sequence coverage of each differentially expressed protein (for the "biotinylated", "glycosylated", and "rest" fractions) are detailed in Table S3. Annotated MS/MS spectra corresponding to the proteins displayed in the Tables 1 and 2 and identified with only one peptide are shown in Figure S4.

In addition to differentially expressed proteins, the current study also highlights proteins that were highly expressed in both primary tumor and its matched metastasis (Supplemental Data, Table S4). These proteins were analyzed against the expression profiles in healthy tissues and according to the publicly available database (Protein Atlas: Knut \& Alice Wallenberg foundation, Uppsala Universitet). In particular for diagnostic and therapeutic applications, proteins with a low or inexistent expression in healthy tissues yet can have an important value when overexpressed in cancer. For example, proteins already used as targets for anti-cancer therapies, such as tenascin ${ }^{28}$ or fibronectin ${ }^{29}$, were weakly or not expressed in the majority of the healthy organs but were highly expressed in both breast tumor and bone metastasis.

Differentially expressed proteins involved in cell migration and/or the acquisition of an aggressive phenotype 
Thirteen out of 63 differentially expressed proteins in the bone metastasis and the primary tumor have been previously associated with cell migration and/or tumor aggressiveness. Interestingly, up- or down-regulated proteins showed a modulation that was in favor of the acquisition of a pro-metastatic phenotype (Table 3A). For example, HLA-A down-regulation in the bone metastatic cancer cells fitted well with the global downregulation or loss of HLA class I and II molecules previously shown to confer invasive cancer cells with the capacity to escape from the host immune defense. ${ }^{30}$ Integrins regulate cell-cell and cell-matrix adhesion and thereby play critical roles in tumor progression and metastasis. Integrin $\alpha 2 \beta 1$ mainly serves as a collagen type I receptor. It is noteworthy that $\alpha 2$ and $\beta 1$ subunits were both found significantly down-regulated in the bone metastatic lesion analyzed in this study. Indeed, integrin $\alpha 2 \beta 1$ has been shown to suppress metastasis in a clinically relevant spontaneous mouse model of breast cancer. ${ }^{31}$ In another study, re-expression of $\alpha 2 \beta 1$ into a poorly differentiated, motile, and highly invasive mammary carcinoma cell line induced a less motile and invasive phenotype in these cells. ${ }^{32}$ Fibulin-2, CD59, and serine protease HtrA1 also appeared to be down-regulated in the bone metastatic lesion when compared to the primary tumor. The decrease in expression of these proteins in breast cancer has been previously described as conferring a selective advantage to cancer cells resulting in a more aggressive phenotype. ${ }^{33-35}$ The reduced expression of fibulin-1 and Sushi domain-containing protein 2 (SUSD2) in bone metastatic cells was consistent with the previously reported role of these proteins in the reduction of cancer cell migration and invasion. ${ }^{36,37}$ We were particularly interested in the differential expression of SUSD2 because its gene has been isolated only recently ${ }^{37}$ and its expression in breast cancer has never been reported. Using specific antiSUSD2 antibodies, we validated its differential expression in our series of matched primary/bone metastases samples. The immunostaining was localized at the plasma membrane of cancer cells. All but 2 bone metastatic samples showed a low SUSD2 staining 
score when compared to their matched primary lesion (t-test, $\mathrm{p}=0.0013$ ) (Figure 3a, b and c, and Table S2). Over-expression of SUSD2 protein in tumor cells reduced or abrogated some of the tumorigenic phenotypes including anchorage-independent growth, migratory, and invasive properties of cancer cells. ${ }^{37}$ Altogether, these data and ours suggest that the decreased cell surface expression of SUSD2 in metastatic cancer cells promoted their invasive potential and their subsequent seeding and growth in the skeleton. Further studies are needed to help clarify the potential function of SUSD2 as a metastasis suppressor gene.

Among the most striking proteins found to be up-regulated in bone-residing breast cancer cells is the activated leukocyte cell adhesion molecule (ALCAM/CD166), whose expression has been previously documented in tumors. This membrane protein is known to act as a regulator of actin cytoskeleton and as such has been linked to the invasive phenotype of breast cancer cells. ${ }^{38}$ Indeed, lower level of CD166 expression is correlated with nodal involvement, grade, clinical stage, poor prognosis, and a higher risk of relapse in bone. ${ }^{39,40} \mathrm{~A}$ recent study ${ }^{41}$ addressed the question of CD166 expression in different metastatic lesions and proved the expression of the protein in all the lesions with a significantly increased CD166 expression in skin metastases. Therefore, we selected CD166 for validation in our collection of primary breast tumors and their matched bone metastases. While the primary tumors showed low CD166 levels, the bone metastatic lesions showed a strong positive staining mainly localized at the membrane and in the cytoplasm of metastatic cells ( $t$-test, $p=0.0019$ ) (Figure 3d, e, and f). Because CD166 is a cell-cell adhesion molecule, its reduced expression in aggressive primary tumors brings to mind the decrease of another cell-cell adhesion protein, e.g. E-cadherin, in invasive cancer cells and during epithelial-to-mesenchymal transition (EMT). A comparable modulation of E-cadherin has been reported in bone metastatic cancer cells where the exit from EMT is marked by an increase in E-cadherin expression and is considered as necessary for tumor growth at sites of metastasis. ${ }^{42}$ 
Interestingly, CD166 was reported to co-localize with E-cadherin in epithelial cells ${ }^{43}$ and it may therefore show similar properties. Other up-regulated proteins implicated in the invasive phenotype (Table 3A) included type IV collagen and LAMP2 (lysosome-associated membrane glycoprotein 2). Both have been previously described as inducers of cancer cell migration with LAMP2 specifically found over-expressed at the cell surface of highly metastatic colon cancer cells. $^{44,45}$

\section{Differentially expressed proteins involved in the bone turnover process}

The settling and proliferation of tumor cells in the bone microenvironment have important consequences on the mechanisms of bone turn-over. ${ }^{46}$ Tumor cells are able to secrete soluble factors, such as interleukins and growth factors, which directly or indirectly interfere with osteoclast and osteoblast functions, leading to osteolytic ${ }^{47}$, osteoblastic ${ }^{48}$, or mixed lesions ${ }^{49}$. In this study, we observed that a number of extracellular matrix and/or secreted proteins identified in bone-residing breast metastatic cells, either up- or downregulated, have been previously reported to possess specific effects on bone remodeling. Most notably, the 14 down-regulated proteins were the ones reported to be in favor of osteoblast differentiation and maturation while the 5 up-regulated proteins are rather known for their pro-osteoclastic functions (Table 3B).

Major down-regulated proteins in the bone metastatic lesion include apolipoprotein E, whose deficiency has been reported in the context of a reduction of bone formation ${ }^{50}$, and thrombospondin-2 and -4 , whose secretion has been shown to coincide with the osteoblastderived ECM organization and the initialization of mineral deposition in the bone extracellular matrix. ${ }^{51,52}$ Conversely, there are a number of proteins which are substantially up-regulated in bone metastases. The most representative examples are cathepsin G, whose activity at the tumor-bone interface plays an important role in breast tumor-induced 
osteolysis $^{53}$, resistin, which is known to increase osteoclastogenesis ${ }^{54}$, and prothrombin, which is overexpressed during osteoclastogenesis in rodents. ${ }^{55}$

Among the proteins expressed in the bone metastase and the breast primary lesion, we noticed that the small leucine-rich proteoglycan (SLRP) family was well represented. ${ }^{56}$ Indeed, among the 15 members reported to date, 7 were identified. Six were significantly down-regulated in the breast cancer metastatic lesion: asporin, lumican, mimecan, decorin, prolargin, and biglycan whereas fibromodulin was not found to be differentially expressed. SLRPs are involved in many biological processes, both in health and disease, including cancer. In normal bone, lumican, mimecan, biglycan, decorin, and prolargin are all implicated in osteoblast-driven bone mineralization. ${ }^{57-62}$ Despite their common role in normal bone formation, SLRPs appear to have distinct functions during cancer progression. In breast cancer tumors, lumican was reported as over-expressed and associated with high tumor grade, low estrogen receptor levels, and young age of patients. ${ }^{63,64}$ High levels of lumican have been correlated with the spread of lymph node metastasis in colorectal cancer ${ }^{65}$ whereas it was reported to inhibit cancer cell migration in a melanoma cell line. ${ }^{66,67}$ Lumican and the two other most studied SLRPs, e.g. decorin and biglycan, have been reported to interact with tyrosine kinase receptors and Toll-like receptors to modulate cellular behavior in terms of migration, proliferation, and tumor growth. ${ }^{56,68}$ Consistent with the down-regulation observed for decorin in our metastatic sample, this SLRP has been recently described in MDA-MB-231 breast cancer cells containing the decorin transgene as reducing bone metastases in breast cancer by diminishing cell growth and motility both in vitro and in vivo. ${ }^{69}$

Among the SLRPs found down-regulated in breast cancer bone-residing cells, asporin is one of the least studied. Asporin acts as a negative regulator of osteoblast mineralization and calcification found primarily in regions surrounding skeletal tissue. ${ }^{70,71}$ It is implicated in a feedback loop with TGF- $\beta$ to cause osteoarthritis by relaxing the bone matrix. ${ }^{72}$ Asporin is a 
rather novel SLRP implicated in breast cancer. An in situ hybridization study demonstrated high asporin transcript levels in breast primary tumors. ${ }^{73}$ However, no specific function in cancer has been identified yet for this SLRP. Therefore, we evaluated asporin expression in our series of matched breast cancer tumors/bone metastases. This SLRP was significantly (ttest, $\mathrm{p}=0.0147)$ down-regulated in the bone metastatic lesions when compared to the matched primary tumors in 6 couples, whereas 3 couples showed no modulated expression and only 1 presented with a higher immunostaining score in the bone metastasis (Figure $3 \mathrm{~g}, \mathrm{~h}$, and i, Table S2). It is important to emphasize that the changes observed at the proteomic level, in contrast to those described at the genomic level, are the final manifestation of a global program, resulting in both up- and down-regulated proteins, altogether conferring specific capabilities to metastatic cancer cells. To complicate matters further, the same protein might have a specific function in primary tumor breast cancer cells and another function in bone-residing breast cancer cells. Therefore, caution is required before drawing final conclusions. For example, the decrease of an SLRP protein (e.g. lumican) level in bone metastases could play a role in favor of bone matrix destruction and be associated with an increased invasive capacity for breast cancer cells at the primary site. ${ }^{63-65}$

\section{Comparison of mass spectrometry data between human clinical material and osteotropic cell line}

We have previously used the MDA-MB-231 human mammary breast cancer cell line and its osteotropic clone named B02 in both transcriptomic ${ }^{13}$ and proteomic ${ }^{14}$ studies aimed at $^{2}$ the identification of bone metastases associated changes at the gene and protein levels, respectively. This model has been successfully utilized in several studies to explore the metastatic behavior of breast cancer. ${ }^{2,74-76}$ Therefore, we deemed important to compare our data to those previously obtained in these cell lines. This is an important step preceding the future studies aimed at explaining the mechanistic role of selected proteins in the process of 
bone metastasis development. Interestingly, among the 417 proteins identified in this study, 80 membrane or extracellular proteins were found in common with our previous cell line data. Considering that a given protein was marked as differentially expressed when it was present more often in one of the disease conditions, 20 proteins shared the same modulation pattern in both data sets (Table S5). This overlap observed in terms of differentially expressed membrane/extracellular proteins between the tissue samples and the cell line is a good indicator of the effectiveness of the proteomic approach used to identify proteins involved in the bone metastatic process. For example, kinectin (KTN1) appeared as up-regulated both in the bone metastasis and B02 cells, suggesting that it could be part of the osteotropic phenotype. Kinectin is the kinesin receptor, an evolutionary conserved integral membrane protein that can be accumulated in integrin-based adhesion complexes. ${ }^{77}$ Little is known about kinectin's involvement in cancer, but the identification of the kinectin gene as a target of mutations in breast and colorectal cancer indicates that it is likely to play a role in these tumors and perhaps in other types of cancer. ${ }^{78}$ Variants of kinectin mRNA were also found to be over-expressed in hepatocellular carcinoma and this alteration may be associated to tumor biology. ${ }^{79}$ More recently, kinectin was also reported to be over-expressed in giant cell tumors of bone, which are cancer cells known to cause osteolytic destruction and to be aggressive in behavior. ${ }^{80}$ Following the rationale that kinectin over-expression has not been validated in our previous study, and considering that its role in cancer progression and metastasis development is still unknown, we selected this protein for further validation. Strong kinectin immunostaining was effectively observed in B02 cells whereas parental MDA-MB-231 cells were negative (Figure 4A: a and b), suggesting that kinectin expression may be associated with the osteotropic phenotype. However, comparative kinectin IHC performed on our set of paired primaries and bone metastases used in this study did not reach statistical significance (data not shown). 
Two proteins of interest, SUSD2 and CD166, which were significantly modulated in the clinical specimens, were further explored in MDA-MB-231/B02 cells. Consistently, CD166, which was up-regulated in the bone metastatic samples, was found up-regulated at the cell surface of B02 cells when compared to the parental cells (Figure 4A: c and d). This observation points to CD166 as a potential marker of osteotropism in breast cancer. SUSD2 was not detectable in either MDA-MB-231 or B02 cells (Figure 4A: e and f), suggesting that this protein is silenced in cells with a metastatic potential. SUSD2 Western blotting performed on MDA-MB-231, B02, and MCF-7 total protein extracts showed positivity only in MCF-7 non-metastatic breast cancer cells (Figure 4B). 


\section{CONCLUSION}

Significant variations of expressed membrane and extracellular matrix proteins are observed in the unique set of breast primary tumor and matched bone metastasis analyzed in this study. They notably concern proteins associated with an aggressive phenotype in breast cancer cells and other proteins apparently associated with bone metabolism. It is noteworthy that our proteomic analysis on one matched case of primary and bone metastatic lesions points to differentially expressed proteins previously reported in larger sample series. One of these is CD166 protein, which is lost in bone residing cancer cells. This observation supports the launching of functional studies aimed at validation of new differentially expressed proteins identified here such as SUSD2 and SLRPs. These investigations could be of particular interest not only for a better understanding of the in vivo scenario of metastasis to bone but also for future development of diagnostic and therapeutic modalities. 


\section{ACKNOWLEDGMENTS}

$\mathrm{AB}$ is a Research Associate and BD is a TELEVIE fellow, both from the National Fund for Scientific Research (NFSR, Belgium). This work was supported by grants from the Research Concerted Action (IDEA project) of the University of Liège (ULg), Belgium; the CEE (FP7 network: ADAMANT-Antibody Derivatives As Molecular Agents for Neoplastic Targeting [HEALTH-F2-2007-201342]), and the Centre Anti-Cancéreux at ULg. The authors are particularly grateful to Dr. Joan Somja and Agnès Delga, from the Department of Pathology (ULg) and BUL - CHU Liège (ULg), respectively. The authors acknowledge the support of the GIGA "Proteomics" and "Genotranscriptomics" platforms of the ULg as well as Pascale Heneaux, Naima Maloujahmoum and Christophe Poulet for their technical assistance. 


\section{FIGURE LEGENDS}

Figure 1: Schematic representation of the method used in this study for the identification of cell surface and extracellular proteins in the primary breast tumor and its matched bone metastasis. Free amine groups of the proteins were labeled with the reactive ester of the biotin and purified using streptavidin affinity chromatography. The proteins were converted into peptides employing tryptic digestion and were analyzed using MS ("biotinylated" fraction, 4 technical replicates). The non-biotinylated proteins were also digested and the glycopeptides were purified. These were separately analyzed using MS ("glycosylated" fraction, 2 technical replicates). Finally, the non-glycosylated peptides were also analyzed in order to recover more potentially accessible proteins ("rest" fraction, 2 technical replicates) and fully exploit the precious sample.

Figure 2: (A) Comparison of the protein subcellular localization profiles of the primary breast tumor and its bone metastasis in the different fractions analyzed ("biotinylated", "glycosylated", and "rest"). Protein subcellular localization was determined using the Uniprot $^{\circledR}$ database, and the proteins marked as membrane, extracellular or secreted were selected for further analysis. (B) Venn diagrams display protein distributions between the different fractions in the primary tumor and its bone metastasis.

Figure 3: Validation of selected differentially expressed proteins between primary breast tumors and their associated bone metastases using immunohistochemistry. Paraffin-embedded tissue sections were immunostained as described in the Materials and Methods section. Higher levels of SUSD2 (a and b) and ASPN (g and h) were detected in the breast tumors 
compared to their paired bone metastases. Higher expression of CD166 (d and e) was detected in bone metastases compared to their primary tumor masses. Statistical analysis of SUSD2 (c), CD166 (f), and ASPN (i) shows a significant modulation of protein expression (one-tailed sample t-test; $\mathrm{p}<0.05^{*} \mathrm{p}<0.01^{* *}$ ) between the 10 primary breast tumors (PT) and their matched bone metastasis (BM). Original magnification: X400.

Figure 4: (A) Detection of KTN1, CD166, and SUSD2 in the MDA-MB-231 cell line and its osteotropic B02 subclone. Paraffin-embedded cell pellet sections were immunostained as described in the Materials and Methods section. Higher levels of KTN1 (a and b) and CD166 (c and d) were detected in the osteotropic B02 cells when compared to their parental cell line MDA-MB-231. SUSD2 was detected neither in MDA-MB-231 (e) nor in the B02 cells (f). (B) Validation of SUSD2 protein expression using Western blot analysis on MDA-MB231/B02 cells and non-metastatic MCF-7 breast cancer cell line. 


\section{Figure 1}

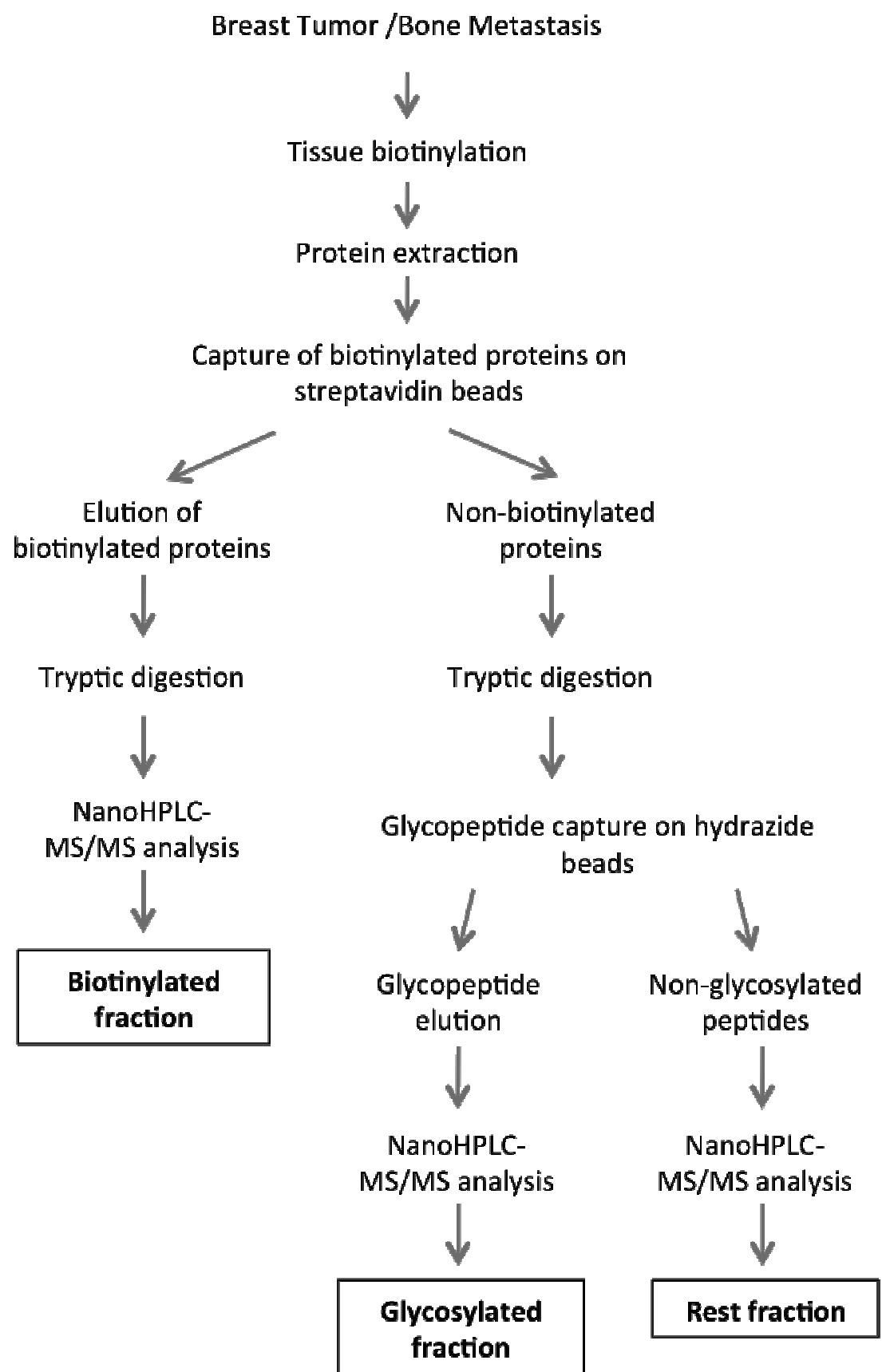


Figure 2

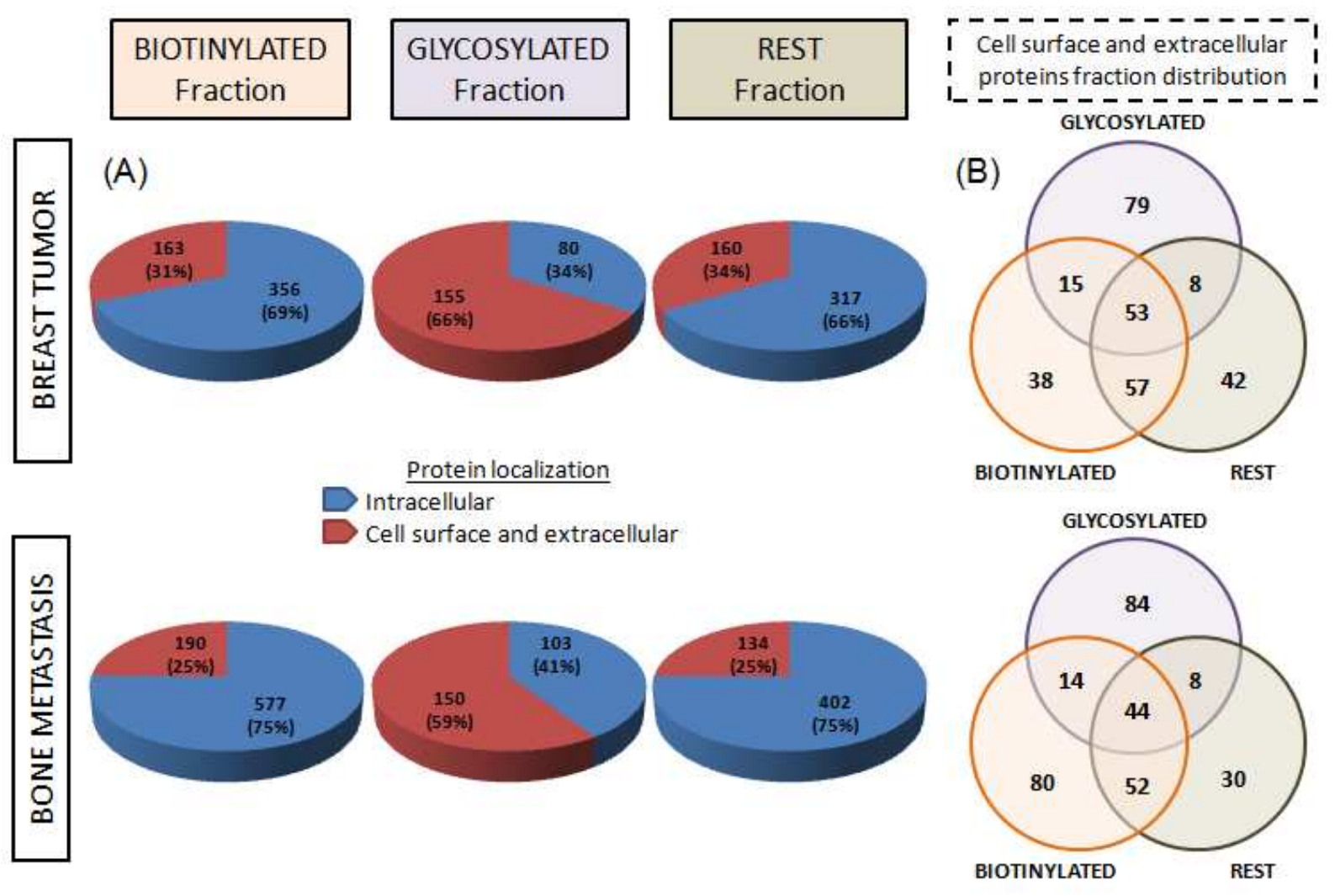


Figure 3
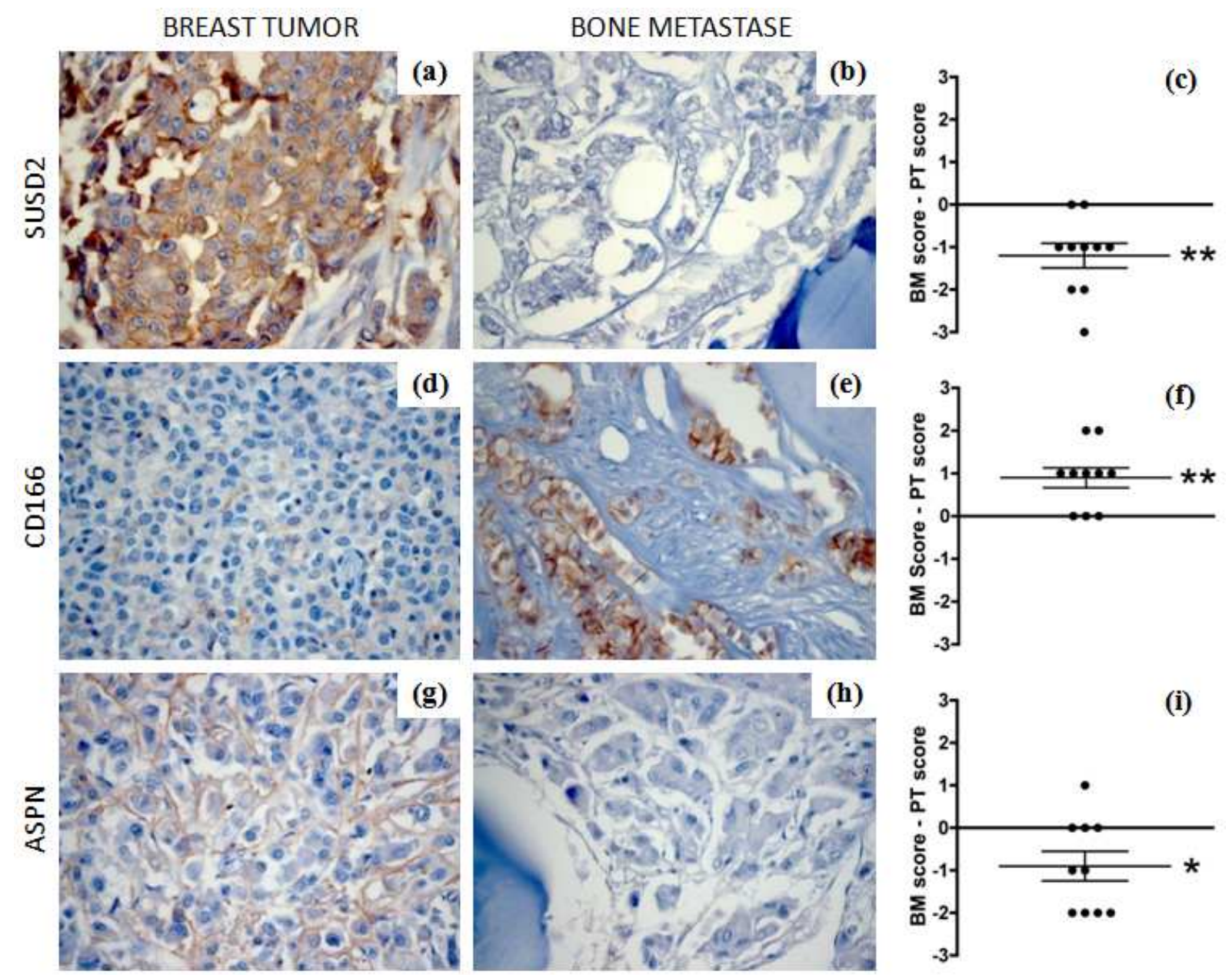


\section{Figure 4}

(A)
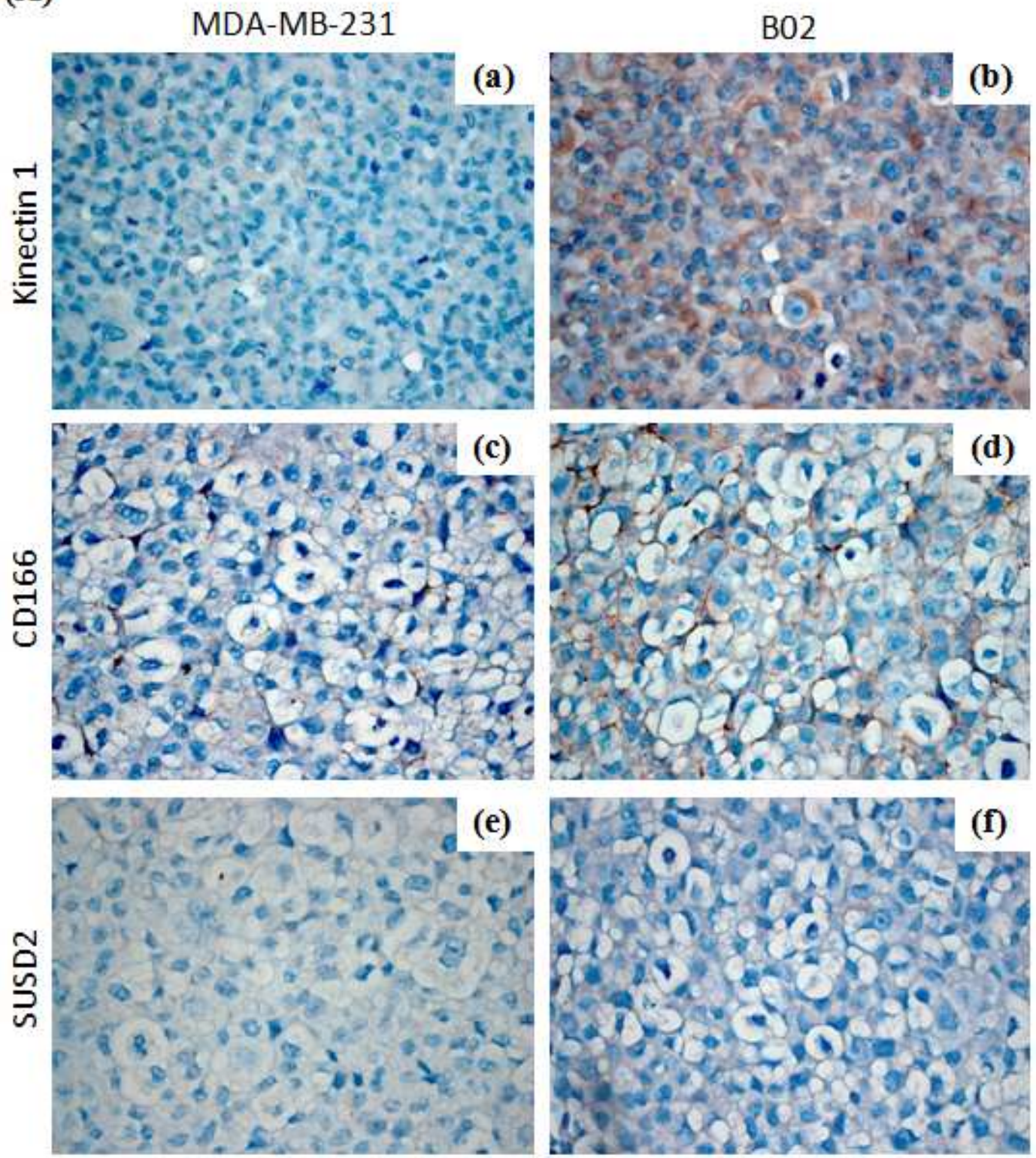

(B)

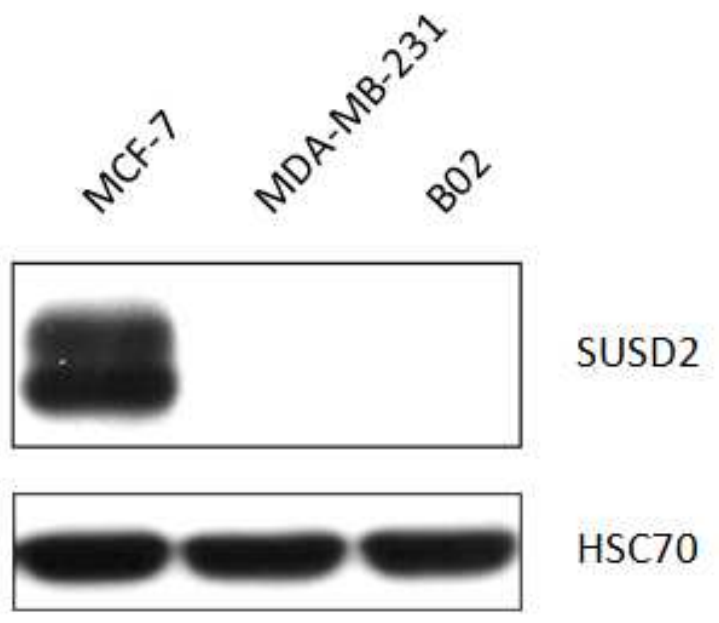


Table 1: Membrane and extracellular proteins identified as down-regulated in the bone metastasis (BM) compared to its primary breast tumor $(\mathrm{PT})^{\mathrm{a}}$.

\begin{tabular}{|c|c|c|c|c|c|c|c|c|c|c|c|c|}
\hline \multirow[b]{2}{*}{$\#$} & \multirow[b]{2}{*}{$\begin{array}{l}\text { Gene } \\
\text { name }\end{array}$} & \multirow[b]{2}{*}{ Protein name } & \multicolumn{3}{|c|}{\begin{tabular}{|c} 
BIOTINYLATED \\
Fraction $(n=4)$
\end{tabular}} & \multicolumn{3}{|c|}{$\begin{array}{c}\text { GLYCOSYLATED } \\
\text { Fraction }(n=2)\end{array}$} & \multicolumn{3}{|c|}{$\begin{array}{c}\text { REST } \\
\text { Fraction }(n=2)\end{array}$} & \multirow[b]{2}{*}{$\begin{array}{c}\text { Subcellular } \\
\text { localization }\end{array}$} \\
\hline & & & PT & BM & $\begin{array}{l}\text { emPAI }^{b} \\
\text { BM/PT } \\
\end{array}$ & PT & BM & $\begin{array}{l}\text { emPAI } \\
\text { BM/PT } \\
\end{array}$ & & BM & $\begin{array}{l}\text { emPAI } \\
\text { BM/PT } \\
\end{array}$ & \\
\hline 1 & ASPN & Asporin & 4 & 0 & & 2 & 2 & -7.54 & 2 & 0 & & $\mathrm{~S} ; \mathrm{E}$ \\
\hline 2 & THBS2 & Thrombospondin-2 & 4 & 0 & & 0 & 0 & & 2 & 0 & & $\mathrm{E}$ \\
\hline 3 & TGFBI & $\begin{array}{l}\text { Transforming growth factor-beta-induced } \\
\text { protein ig-h3 }\end{array}$ & 4 & 0 & & 0 & 0 & & 2 & 1 & & $\mathrm{~S} ; \mathrm{E}$ \\
\hline 4 & MIME & Mimecan & 4 & 0 & & 0 & 0 & & 2 & 1 & & $\mathrm{~S} ; \mathrm{E}$ \\
\hline 5 & PEDF & Serpin-F1 & 4 & 0 & & 2 & 2 & -2.15 & 2 & 1 & & $\mathrm{~S}$ \\
\hline 6 & AEBP1 & Adipocyte enhancer-binding protein 1 & 4 & 1 & & 2 & 2 & -14.83 & 2 & 0 & & $\mathrm{~S} ; \mathrm{Cy} ; \mathrm{N}$ \\
\hline 7 & DCN & Decorin & 4 & 1 & & 2 & 2 & -2.33 & 2 & 1 & & $\mathrm{~S} ; \mathrm{E}$ \\
\hline 8 & THBS4 & Thrombospondin-4 & 4 & 1 & & 0 & 0 & & 2 & 1 & & $\mathrm{E}$ \\
\hline 9 & PRELP & Prolargin & 4 & 2 & -3.72 & 2 & 2 & -2.51 & 2 & 1 & & $\mathrm{~S} ; \mathrm{E}$ \\
\hline 10 & VTN & Vitronectin & 4 & 2 & -4.53 & 2 & 2 & -2.65 & 2 & 1 & & $\mathrm{~S} ; \mathrm{E}$ \\
\hline 11 & THBS1 & Thrombospondin-1 & 4 & 4 & -14.53 & 2 & 1 & & 2 & 1 & & $\mathrm{E}$ \\
\hline 12 & POSTN & Periostin & 4 & 4 & -6.66 & 2 & 2 & -4.96 & 2 & 2 & -5.29 & $\mathrm{~S} ; \mathrm{E}$ \\
\hline 13 & THY1 & Thy-1 membrane glycoprotein & 2 & 0 & & 2 & 2 & -1.43 & 0 & 0 & & $\mathrm{M}$ \\
\hline 14 & HLA-A & $\begin{array}{l}\text { HLA class I histocompatibility antigen, A- } 1 \\
\text { alpha chain }\end{array}$ & 2 & 0 & & 0 & 0 & & 0 & 0 & & M \\
\hline 15 & FBLN2 & Fibulin-2 & 3 & 0 & & 2 & 0 & & 2 & 0 & & $\mathrm{~S} ; \mathrm{E}$ \\
\hline 16 & PZP & Pregnancy zone protein & 2 & 0 & & 0 & 0 & & 1 & 0 & & $S$ \\
\hline 17 & ITGB1 & Integrin beta- 1 & 3 & 1 & & 2 & 0 & & 2 & 0 & & $\mathrm{M}$ \\
\hline 18 & FBLN1 & Fibulin-1 & 3 & 1 & & 1 & 0 & & 1 & 0 & & $\mathrm{~S} ; \mathrm{E}$ \\
\hline 19 & APOH & Apolipoprotein $\mathrm{H}$ & 3 & 0 & & 2 & 2 & -1.69 & 1 & 0 & & $\mathrm{~S}$ \\
\hline 20 & COL14A1 & Collagen alpha-1(XIV) chain & 3 & 0 & & 2 & 1 & & 2 & 1 & & $\mathrm{~S} ; \mathrm{E}$ \\
\hline 21 & HTRA1 & Serine protease HTRA1 & 3 & 0 & & 0 & 0 & & 0 & 0 & & $S$ \\
\hline 22 & SUSD2 & Sushi domain-containing protein 2 & 3 & 0 & & 0 & 0 & & 1 & 0 & & $\mathrm{M}$ \\
\hline
\end{tabular}




\begin{tabular}{|c|c|c|c|c|c|c|c|c|c|c|c|c|}
\hline 23 & TNA & Tetranectin & 0 & 0 & & 0 & 0 & & 2 & 0 & & $\mathrm{~S}$ \\
\hline 24 & SATT & Neutral amino acid transporter A & 0 & 0 & & 0 & 0 & & 2 & 0 & & M \\
\hline 25 & CPN2 & Carboxypeptidase $\mathrm{N}$ subunit 2 & 0 & 0 & & 2 & 0 & & 0 & 0 & & $\mathrm{~S}$ \\
\hline 26 & ITGA2 & Integrin alpha-2 & 0 & 0 & & 2 & 0 & & 0 & 0 & & M \\
\hline 27 & ITGA5 & Integrin alpha-5 & 0 & 0 & & 2 & 0 & & 0 & 0 & & M \\
\hline 28 & MFAP4 & Microfibril-associated glycoprotein 4 & 0 & 0 & & 2 & 0 & & 0 & 0 & & $\mathrm{~S}$ \\
\hline 29 & TSPAN8 & Tetraspanin-8 & 0 & 0 & & 2 & 0 & & 0 & 0 & & M \\
\hline 30 & CD59 & CD59 glycoprotein & 0 & 0 & & 0 & 0 & & 2 & 0 & & $\mathrm{M} ; \mathrm{S}$ \\
\hline 31 & HSPG2 & Perlecan & 2 & 1 & & 0 & 0 & & 2 & 0 & & $\mathrm{~S} ; \mathrm{E}$ \\
\hline 32 & APOE & Apolipoprotein E & 4 & 3 & -4.04 & 0 & 0 & & 2 & 2 & -3.31 & $\mathrm{~S}$ \\
\hline 33 & LUM & Lumican & 4 & 3 & -2.11 & 2 & 2 & -7.77 & 2 & 1 & & $\mathrm{E}$ \\
\hline 34 & BGN & Biglycan & 4 & 3 & -2.32 & 2 & 2 & -5.02 & 2 & 2 & -3.69 & E \\
\hline
\end{tabular}

${ }^{a}$ The selection of the proteins was done as described in the Results section. ${ }^{b}$ For proteins showing the same presence in one of the fractions, emPAI ratio (semi-quantitative data) has been included when it was down-regulated in the metastasis (ratio $<-4) .{ }^{c}$ Potential subcellular location:

S, secreted; E, extracellular; M, cell membrane; Cy, cytoplasm; N, nucleus. 
Table 2: Membrane and extracellular proteins identified as up-regulated in the bone metastasis (BM) compared to its primary breast tumor (PT) a.

\begin{tabular}{|c|c|c|c|c|c|c|c|c|c|c|c|c|}
\hline \multirow[b]{2}{*}{$\#$} & \multirow[b]{2}{*}{$\begin{array}{l}\text { Gene } \\
\text { name }\end{array}$} & \multirow[b]{2}{*}{ Protein name } & \multicolumn{3}{|c|}{\begin{tabular}{|c|} 
BIOTINYLATED \\
Fraction $(\mathrm{n}=4)$
\end{tabular}} & \multicolumn{3}{|c|}{\begin{tabular}{|c|} 
GLYCOSYLATED \\
Fraction $(\mathrm{n}=2)$
\end{tabular}} & \multicolumn{3}{|c|}{$\begin{array}{c}\text { REST } \\
\text { Fraction }(n=2)\end{array}$} & \multirow[b]{2}{*}{$\begin{array}{l}\text { Subcellular } \\
\text { localization }{ }^{\mathrm{c}}\end{array}$} \\
\hline & & & PT & BM & $\begin{array}{l}\text { emPAI }^{b} \\
\text { BM/PT }\end{array}$ & PT & BM & $\begin{array}{l}\text { emPAI } \\
\text { BM/PT } \\
\end{array}$ & PT & $\mathbf{B M}$ & $\begin{array}{l}\text { emPAI } \\
\text { BM/PT }\end{array}$ & \\
\hline 1 & MYH7B & Myosin-7B & 0 & 4 & & 0 & 0 & & 0 & 1 & & $\mathrm{M}$ \\
\hline 2 & MYL3 & Myosin light chain 3 & 0 & 4 & & 0 & 2 & & 0 & 2 & & $\mathrm{Cy} ; \mathrm{E}$ \\
\hline 3 & ALPL & Alkaline phosphatase, tissue-nonspecific isozyme & 0 & 4 & & 0 & 0 & & 0 & 1 & & M \\
\hline 4 & KTN1 & Kinectin & 0 & 3 & & 0 & 0 & & 0 & 0 & & M \\
\hline 5 & NUCB2 & Nucleobindin-2 & 0 & 3 & & 0 & 0 & & 0 & 0 & & $\mathrm{M} ; \mathrm{S} ; \mathrm{Cy}$ \\
\hline 6 & ALCAM & CD166 antigen & 0 & 3 & & 1 & 1 & & 0 & 0 & & $\mathrm{M}$ \\
\hline 7 & LAMC1 & Laminin subunit gamma-1 & 0 & 3 & & 2 & 2 & 1.59 & 0 & 0 & & $S ; E$ \\
\hline 8 & COL4A2 & Collagen alpha-2(IV) chain & 0 & 3 & & 0 & 0 & & 1 & 1 & & $S ; E$ \\
\hline 9 & HINT2 & Histidine triad nucleotide-binding protein 2 & 0 & 2 & & 0 & 0 & & 0 & 0 & & $\mathrm{~S}$ \\
\hline 10 & RETN & Resistin & 0 & 2 & & 0 & 0 & & 0 & 0 & & $\mathrm{~S}$ \\
\hline 11 & $\mathrm{~F} 2$ & Prothrombin & 0 & 2 & & 0 & 0 & & 0 & 0 & & $\mathrm{~S} ; \mathrm{E}$ \\
\hline 12 & PMP2 & Myelin P2 protein & 0 & 2 & & 0 & 0 & & 0 & 0 & & $\mathrm{Cy} ; \mathrm{M}$ \\
\hline 13 & TCTE3 & Tctex 1 domain-containing protein 3 & 0 & 2 & & 0 & 0 & & 0 & 0 & & $\mathrm{Cy} ; \mathrm{M}$ \\
\hline 14 & HNRPU & Heterogeneous nuclear ribonucleoprotein $\mathrm{U}$ & 0 & 2 & & 1 & 2 & & 2 & 2 & 2.56 & $\mathrm{~N} ; \mathrm{M}$ \\
\hline 15 & CTSG & Cathepsin G & 0 & 1 & & 0 & 1 & & 0 & 2 & & $\mathrm{M} ; \mathrm{Cy} ; \mathrm{E}$ \\
\hline 16 & LAMP2 & Lysosome-associated membrane glycoprotein 2 & 0 & 1 & & 2 & 2 & 3.85 & 0 & 2 & & M \\
\hline 17 & TFRC & Transferrin receptor protein 1 & 0 & 1 & & 0 & 2 & & 0 & 1 & & M \\
\hline 18 & LRPAP1 & Alpha-2-macroglobulin receptor-associated protein & 0 & 0 & & 0 & 2 & & 0 & 0 & & $\mathrm{M} ; \mathrm{Cy}$ \\
\hline 19 & AOC3 & Membrane primary amine oxidase & 0 & 0 & & 0 & 2 & & 0 & 0 & & M \\
\hline 20 & CASD1 & CAS1 domain-containing protein 1 & 0 & 0 & & 0 & 2 & & 0 & 0 & & M \\
\hline 21 & CGM6 & $\begin{array}{l}\text { Carcinoembryonic antigen-related cell adhesion } \\
\text { molecule } 8\end{array}$ & 0 & 0 & & 0 & 2 & & 0 & 0 & & M \\
\hline 22 & CLPTM1 & Cleft lip and palate transmembrane protein 1 & 0 & 0 & & 0 & 2 & & 0 & 0 & & M \\
\hline
\end{tabular}




\begin{tabular}{|c|c|c|c|c|c|c|c|c|c|}
\hline 23 & CPVL & Probable serine carboxypeptidase CPVL & 0 & 0 & 0 & 2 & & $0 \quad 0$ & $\mathrm{E}$ \\
\hline 24 & ELANE & Leukocyte elastase & 0 & 0 & 0 & 2 & & 0 & $\mathrm{Cy} ; \mathrm{M}$ \\
\hline 25 & GLUT1 & $\begin{array}{l}\text { Solute carrier family } 2 \text {, facilitated glucose } \\
\text { transporter member } 1\end{array}$ & 0 & 0 & 0 & 2 & & 0 & M \\
\hline 26 & SORT1 & Sortilin & 0 & 0 & 0 & 2 & & 0 & $\mathrm{M}$ \\
\hline 27 & LAMA4 & Laminin subunit alpha-4 & 1 & 1 & 0 & 2 & & 0 & $\mathrm{~S} ; \mathrm{E}$ \\
\hline 28 & PRTN3 & Myeloblastin & 0 & 0 & 0 & 0 & & 2 & $\mathrm{M}$ \\
\hline 29 & MDU1 & 4F2 cell-surface antigen heavy chain & 0 & 0 & 2 & 2 & 1.33 & 0 & $\mathrm{M}$ \\
\hline
\end{tabular}

${ }^{a}$ The selection of the proteins was done as described in the Results section. ${ }^{b}$ For proteins showing the same presence in one of the fractions, emPAI ratio (semi-quantitative data) has been included when it was up-regulated in the metastasis (ratio $>4$ ). ${ }^{\mathrm{c}}$ Potential subcellular location: $\mathrm{S}$, secreted; E, extracellular; M, cell membrane; Cy, cytoplasm; N, nucleus. 
Table 3: Representative differentially expressed proteins potentially associated with bone metastases and found as down- $(\downarrow)$ or up- $(\uparrow)$ regulated in the bone metastasis when compared with the primary breast tumor.

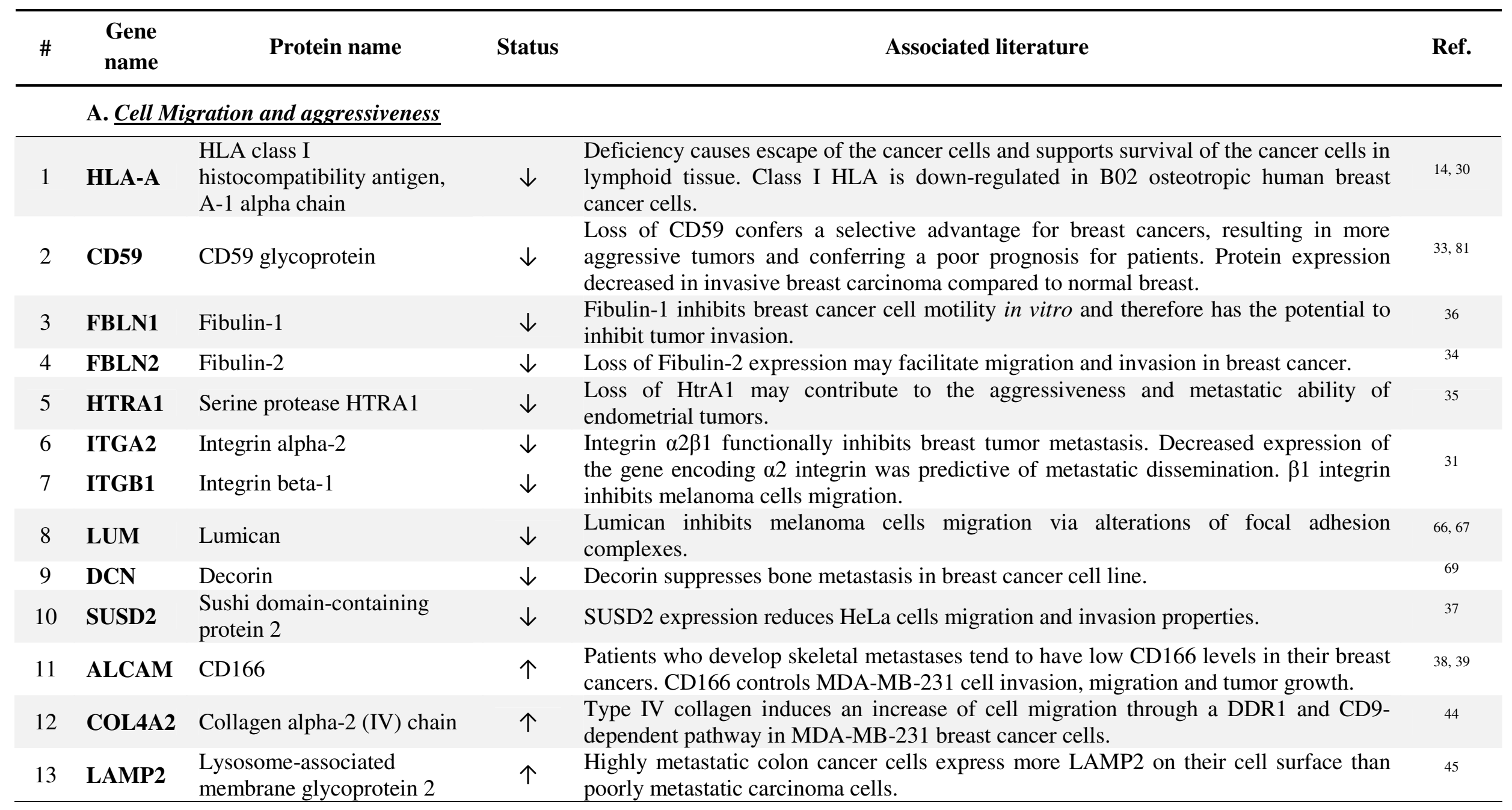




\section{B. Mineralization and bone marker}

\begin{tabular}{|c|c|c|c|c|c|}
\hline 14 & APOE & Apolipoprotein E & $\downarrow$ & $\begin{array}{l}\text { Apolipoprotein E deficiency enhances the reduction of bone formation induced by the } \\
\text { stimulation of p53-mediated apoptosis in osteoblastic cells. }\end{array}$ & 50 \\
\hline 15 & ASPN & Asporin & $\downarrow$ & Asporin has a role in osteoblast-driven collagen biomineralization activity. & 58 \\
\hline 16 & FBLN1 & Fibulin-1 & $\downarrow$ & Fibulin-1 and -2 seem to be important components of the extracellular matrix of & \\
\hline 17 & FBLN2 & Fibulin-2 & $\downarrow$ & $\begin{array}{l}\text { osteoblasts and are likely to negatively influence the proliferation rate of hematopoietic } \\
\text { stem cells. }\end{array}$ & 82 \\
\hline 18 & LUM & Lumican & $\downarrow$ & $\begin{array}{l}\text { Lumican is a significant proteoglycan component of bone matrix, which is secreted by } \\
\text { differentiating and mature osteoblasts. }\end{array}$ & 59 \\
\hline 19 & OGN & Mimecan & $\downarrow$ & $\begin{array}{l}\text { Increased expression of mimecan in the early proliferation stage of cultured } \\
\text { osteoblastic cells may play an important role in the stimulation of bone formation. }\end{array}$ & 60 \\
\hline 20 & PEDF & Serpin-F1 & $\downarrow$ & Serpin-F1 is possibly involved in bone homeostasis as an inhibitor of bone resorption. & 83 \\
\hline 21 & BGN & Biglycan & $\downarrow$ & Biglycan promotes osteoblast differentiation and matrix mineralization. & 61 \\
\hline 22 & DCN & Decorin & $\downarrow$ & Asporin competes with decorin to promote osteoblast mineralization. & 58 \\
\hline 23 & POSTN & Periostin & $\downarrow$ & $\begin{array}{l}\text { Periostin is expressed in vivo and in vitro during the stages of osteoblast differentiation } \\
\text { and maturation. }\end{array}$ & 84 \\
\hline 24 & PRELP & Prolargin & $\downarrow$ & $\begin{array}{l}\text { Prolargin reduces osteoclast number and activity in ovariectomized mice, underlying } \\
\text { its physiological and/or pathological importance in skeletal remodeling. }\end{array}$ & 62 \\
\hline 25 & TNA & Tetranectin & $\downarrow$ & $\begin{array}{l}\text { Down-regulation of tetranectin expression in human osteoblastic cells is correlated } \\
\text { with inhibition of mineralization. }\end{array}$ & 85 \\
\hline 26 & THBS2 & Thrombospondin-2 & $\downarrow$ & $\begin{array}{l}\text { TSP2 may promote mineralization, by facilitating proper organization of the } \\
\text { osteoblast-derived ECM. }\end{array}$ & 51 \\
\hline 27 & THBS4 & Thrombospondin-4 & $\downarrow$ & $\begin{array}{l}\text { TSP4 transcript first appears in the mesenchyme surrounding bone anlage coinciding } \\
\text { with the initial stages of osteogenesis. }\end{array}$ & 52 \\
\hline 28 & CTSG & Cathepsin G & $\uparrow$ & $\begin{array}{l}\text { Cathepsin G activity at the tumor-bone interface plays an important role in mammary } \\
\text { tumor-induced osteolysis. }\end{array}$ & 53 \\
\hline 29 & KTN1 & Kinectin & $\uparrow$ & $\begin{array}{l}\text { Kinectin is up-regulated in the B02 osteotropic breast cancer cell line compared to the } \\
\text { non osteotropic MDA-MB-231. }\end{array}$ & 14 \\
\hline 30 & ALPC & $\begin{array}{l}\text { Alkaline phosphatase, tissue- } \\
\text { nonspecific isozyme }\end{array}$ & $\uparrow$ & $\begin{array}{l}\text { Elevated levels of alkaline phosphatase indicates high rate of bone degradation in } \\
\text { breast metastatic cancer. }\end{array}$ & 86 \\
\hline 31 & RETN & Resistin & $\uparrow$ & $\begin{array}{l}\text { Resistin increased the number of differentiated osteoclasts and stimulated NFkappaB } \\
\text { promoter activity, indicating a role in osteoclastogenesis. }\end{array}$ & 54 \\
\hline 32 & F2 & Prothrombin & $\uparrow$ & Prothrombin expression is increased during rodent osteoclastogenesis. & 55 \\
\hline
\end{tabular}




\section{REFERENCES}

1. Greenlee, R. T.; Hill-Harmon, M. B.; Murray, T.; Thun, M., Cancer statistics, 2001. CA Cancer J Clin 2001, 51, (1), 15-36.

2. Fournier, P. G.; Stresing, V.; Ebetino, F. H.; Clezardin, P., How do bisphosphonates inhibit bone metastasis in vivo? Neoplasia 2010, 12, (7), 571-8.

3. Chambers, A. F.; Groom, A. C.; MacDonald, I. C., Dissemination and growth of cancer cells in metastatic sites. Nat Rev Cancer 2002, 2, (8), 563-72.

4. Coleman, R. E.; Guise, T. A.; Lipton, A.; Roodman, G. D.; Berenson, J. R.; Body, J. J.; Boyce, B. F.; Calvi, L. M.; Hadji, P.; McCloskey, E. V.; Saad, F.; Smith, M. R.; Suva, L. J.; Taichman, R. S.; Vessella, R. L.; Weilbaecher, K. N., Advancing treatment for metastatic bone cancer: consensus recommendations from the Second Cambridge Conference. Clin Cancer Res 2008, 14, (20), 6387-95.

5. Bhattacharyya, S.; Byrum, S.; Siegel, E. R.; Suva, L. J., Proteomic analysis of bone cancer: a review of current and future developments. Expert Rev Proteomics 2007, 4, (3), 371-8.

6. $\quad$ Kang, Y.; Siegel, P. M.; Shu, W.; Drobnjak, M.; Kakonen, S. M.; Cordon-Cardo, C.; Guise, T. A.; Massague, J., A multigenic program mediating breast cancer metastasis to bone. Cancer Cell 2003, 3, (6), 537-49.

7. Suzuki, M.; Tarin, D., Gene expression profiling of human lymph node metastases and matched primary breast carcinomas: clinical implications. Mol Oncol 2007, 1, (2), 172-80.

8. Aguirre-Ghiso, J. A., Models, mechanisms and clinical evidence for cancer dormancy. Nat Rev Cancer 2007, 7, (11), 834-46.

9. Li, J.; Gromov, P.; Gromova, I.; Moreira, J. M.; Timmermans-Wielenga, V.; Rank, F.; Wang, K.; Li, S.; Li, H.; Wiuf, C.; Yang, H.; Zhang, X.; Bolund, L.; Celis, J. E., Omics-based profiling of carcinoma of the breast and matched regional lymph node metastasis. Proteomics 2008, 8, (23-24), 5038-52.

10. Thongwatchara, P.; Promwikorn, W.; Srisomsap, C.; Chokchaichamnankit, D.; Boonyaphiphat, P.; Thongsuksai, P., Differential protein expression in primary breast cancer and matched axillary node metastasis. Oncol Rep 2011.

11. Ho, J.; Kong, J. W.; Choong, L. Y.; Loh, M. C.; Toy, W.; Chong, P. K.; Wong, C. H.; Wong, C. Y.; Shah, N.; Lim, Y. P., Novel breast cancer metastasis-associated proteins. J Proteome Res 2009, 8, (2), 583-94.

12. Chen, H.; Pimienta, G.; Gu, Y.; Sun, X.; Hu, J.; Kim, M. S.; Chaerkady, R.; Gucek, M.; Cole, R. N.; Sukumar, S.; Pandey, A., Proteomic characterization of Her2/neu-overexpressing breast cancer cells. Proteomics 2010, 10, (21), 3800-10.

13. Bellahcene, A.; Bachelier, R.; Detry, C.; Lidereau, R.; Clezardin, P.; Castronovo, V., Transcriptome analysis reveals an osteoblast-like phenotype for human osteotropic breast cancer cells. Breast Cancer Res Treat 2007, 101, (2), 135-48.

14. Kischel, P.; Guillonneau, F.; Dumont, B.; Bellahcene, A.; Stresing, V.; Clezardin, P.; De Pauw, E. A.; Castronovo, V., Cell membrane proteomic analysis identifies proteins differentially expressed in osteotropic human breast cancer cells. Neoplasia 2008, 10, (9), 1014-20.

15. Turtoi, A.; Dumont, B.; Greffe, Y.; Blomme, A.; Mazzucchelli, G.; Delvenne, P.; Mutijima, E. N.; Lifrange, E.; De Pauw, E.; Castronovo, V., Novel Comprehensive Approach for Accessible Biomarker Identification and Absolute Quantification from Precious Human Tissues. Journal of proteome research 2011, 10, (7), 3160-3182.

16. Segal, E.; Friedman, N.; Koller, D.; Regev, A., A module map showing conditional activity of expression modules in cancer. Nature genetics 2004, 36, (10), 1090-8.

17. Koeneman, K. S.; Yeung, F.; Chung, L. W., Osteomimetic properties of prostate cancer cells: a hypothesis supporting the predilection of prostate cancer metastasis and growth in the bone environment. The Prostate 1999, 39, (4), 246-61. 
18. Castronovo, V.; Kischel, P.; Guillonneau, F.; de Leval, L.; Defechereux, T.; De Pauw, E.; Neri, D.; Waltregny, D., Identification of specific reachable molecular targets in human breast cancer using a versatile ex vivo proteomic method. Proteomics 2007, 7, (8), 1188-96.

19. Scheurer, S. B.; Roesli, C.; Neri, D.; Elia, G., A comparison of different biotinylation reagents, tryptic digestion procedures, and mass spectrometric techniques for 2-D peptide mapping of membrane proteins. Proteomics 2005, 5, (12), 3035-9.

20. Nesvizhskii, A. I.; Aebersold, R., Interpretation of shotgun proteomic data: the protein inference problem. Mol Cell Proteomics 2005, 4, (10), 1419-40.

21. Perkins, D. N.; Pappin, D. J.; Creasy, D. M.; Cottrell, J. S., Probability-based protein identification by searching sequence databases using mass spectrometry data. Electrophoresis 1999, 20, (18), 3551-67.

22. Ishihama, Y.; Oda, Y.; Tabata, T.; Sato, T.; Nagasu, T.; Rappsilber, J.; Mann, M., Exponentially modified protein abundance index (emPAl) for estimation of absolute protein amount in proteomics by the number of sequenced peptides per protein. Mol Cell Proteomics 2005, 4, (9), 1265-72.

23. Peyruchaud, O.; Winding, B.; Pecheur, I.; Serre, C. M.; Delmas, P.; Clezardin, P., Early detection of bone metastases in a murine model using fluorescent human breast cancer cells: application to the use of the bisphosphonate zoledronic acid in the treatment of osteolytic lesions. Journal of bone and mineral research : the official journal of the American Society for Bone and Mineral Research 2001, 16, (11), 2027-34.

24. Weigelt, B.; Glas, A. M.; Wessels, L. F.; Witteveen, A. T.; Peterse, J. L.; van't Veer, L. J., Gene expression profiles of primary breast tumors maintained in distant metastases. Proceedings of the National Academy of Sciences of the United States of America 2003, 100, (26), 15901-5.

25. Ramaswamy, S.; Ross, K. N.; Lander, E. S.; Golub, T. R., A molecular signature of metastasis in primary solid tumors. Nature genetics 2003, 33, (1), 49-54.

26. van de Vijver, M. J.; He, Y. D.; van't Veer, L. J.; Dai, H.; Hart, A. A.; Voskuil, D. W.; Schreiber, G. J.; Peterse, J. L.; Roberts, C.; Marton, M. J.; Parrish, M.; Atsma, D.; Witteveen, A.; Glas, A.; Delahaye, L.; van der Velde, T.; Bartelink, H.; Rodenhuis, S.; Rutgers, E. T.; Friend, S. H.; Bernards, R., A geneexpression signature as a predictor of survival in breast cancer. The New England journal of medicine 2002, 347, (25), 1999-2009.

27. Klein, A.; Olendrowitz, C.; Schmutzler, R.; Hampl, J.; Schlag, P. M.; Maass, N.; Arnold, N.; Wessel, R.; Ramser, J.; Meindl, A.; Scherneck, S.; Seitz, S., Identification of brain- and bone-specific breast cancer metastasis genes. Cancer letters 2009, 276, (2), 212-20.

28. Brack, S. S.; Silacci, M.; Birchler, M.; Neri, D., Tumor-targeting properties of novel antibodies specific to the large isoform of tenascin-C. Clin Cancer Res 2006, 12, (10), 3200-8.

29. Sauer, S.; Erba, P. A.; Petrini, M.; Menrad, A.; Giovannoni, L.; Grana, C.; Hirsch, B.; Zardi, L.; Paganelli, G.; Mariani, G.; Neri, D.; Durkop, H.; Menssen, H. D., Expression of the oncofetal ED-Bcontaining fibronectin isoform in hematologic tumors enables ED-B-targeted 131/-L19SIP radioimmunotherapy in Hodgkin lymphoma patients. Blood 2009, 113, (10), 2265-74.

30. Passlick, B.; Pantel, K.; Kubuschok, B.; Angstwurm, M.; Neher, A.; Thetter, O.; Schweiberer, L.; Izbicki, J. R., Expression of MHC molecules and ICAM-1 on non-small cell lung carcinomas: association with early lymphatic spread of tumour cells. Eur J Cancer 1996, 32A, (1), 141-5.

31. Ramirez, N. E.; Zhang, Z.; Madamanchi, A.; Boyd, K. L.; O'Rear, L. D.; Nashabi, A.; Li, Z.; Dupont, W. D.; Zijlstra, A.; Zutter, M. M., The alphabeta integrin is a metastasis suppressor in mouse models and human cancer. J Clin Invest 2011, 121, (1), 226-37.

32. Zutter, M. M.; Santoro, S. A.; Staatz, W. D.; Tsung, Y. L., Re-expression of the alpha 2 beta 1 integrin abrogates the malignant phenotype of breast carcinoma cells. Proceedings of the National Academy of Sciences of the United States of America 1995, 92, (16), 7411-5.

33. Madjd, Z.; Pinder, S. E.; Paish, C.; Ellis, I. O.; Carmichael, J.; Durrant, L. G., Loss of CD59 expression in breast tumours correlates with poor survival. J Pathol 2003, 200, (5), 633-9. 
34. Yi, C. H.; Smith, D. J.; West, W. W.; Hollingsworth, M. A., Loss of fibulin-2 expression is associated with breast cancer progression. Am J Pathol 2007, 170, (5), 1535-45.

35. Mullany, S. A.; Moslemi-Kebria, M.; Rattan, R.; Khurana, A.; Clayton, A.; Ota, T.; Mariani, A.; Podratz, K. C.; Chien, J.; Shridhar, V., Expression and functional significance of HtrA1 loss in endometrial cancer. Clin Cancer Res 2011, 17, (3), 427-36.

36. Hayashido, Y.; Lucas, A.; Rougeot, C.; Godyna, S.; Argraves, W. S.; Rochefort, H., Estradiol and fibulin-1 inhibit motility of human ovarian- and breast-cancer cells induced by fibronectin. Int $J$ Cancer 1998, 75, (4), 654-8.

37. Sugahara, T.; Yamashita, Y.; Shinomi, M.; Yamanoha, B.; Iseki, H.; Takeda, A.; Okazaki, Y.; Hayashizaki, Y.; Kawai, K.; Suemizu, H.; Andoh, T., Isolation of a novel mouse gene, mSVS-1/SUSD2, reversing tumorigenic phenotypes of cancer cells in vitro. Cancer Sci 2007, 98, (6), 900-8.

38. Wiiger, M. T.; Gehrken, H. B.; Fodstad, O.; Maelandsmo, G. M.; Andersson, Y., A novel human recombinant single-chain antibody targeting CD166/ALCAM inhibits cancer cell invasion in vitro and in vivo tumour growth. Cancer Immunol Immunother 2010, 59, (11), 1665-74.

39. Davies, S. R.; Dent, C.; Watkins, G.; King, J. A.; Mokbel, K.; Jiang, W. G., Expression of the cell to cell adhesion molecule, ALCAM, in breast cancer patients and the potential link with skeletal metastasis. Oncol Rep 2008, 19, (2), 555-61.

40. King, J. A.; Ofori-Acquah, S. F.; Stevens, T.; Al-Mehdi, A. B.; Fodstad, O.; Jiang, W. G., Activated leukocyte cell adhesion molecule in breast cancer: prognostic indicator. Breast Cancer Res 2004, 6, (5), R478-87.

41. Ihnen, M.; Kilic, E.; Kohler, N.; Loning, T.; Witzel, I.; Hagel, C.; Holler, S.; Kersten, J. F.; Muller, V.; Janicke, F.; Milde-Langosch, K., Protein expression analysis of ALCAM and CEACAM6 in breast cancer metastases reveals significantly increased ALCAM expression in metastases of the skin. $J$ Clin Pathol 2011, 64, (2), 146-52.

42. Putzke, A. P.; Ventura, A. P.; Bailey, A. M.; Akture, C.; Opoku-Ansah, J.; Celiktas, M.; Hwang, M. S.; Darling, D. S.; Coleman, I. M.; Nelson, P. S.; Nguyen, H. M.; Corey, E.; Tewari, M.; Morrissey, C.; Vessella, R. L.; Knudsen, B. S., Metastatic progression of prostate cancer and e-cadherin regulation by zeb1 and SRC family kinases. The American journal of pathology 2011, 179, (1), 400-10.

43. Jiang, W. G., E-cadherin and its associated protein catenins, cancer invasion and metastasis. The British journal of surgery 1996, 83, (4), 437-46.

44. Castro-Sanchez, L.; Soto-Guzman, A.; Navarro-Tito, N.; Martinez-Orozco, R.; Salazar, E. P., Native type IV collagen induces cell migration through a CD9 and DDR1-dependent pathway in MDAMB-231 breast cancer cells. Eur J Cell Biol 2010, 89, (11), 843-52.

45. Saitoh, O.; Wang, W. C.; Lotan, R.; Fukuda, M., Differential glycosylation and cell surface expression of lysosomal membrane glycoproteins in sublines of a human colon cancer exhibiting distinct metastatic potentials. J Biol Chem 1992, 267, (8), 5700-11.

46. Clezardin, P.; Teti, A., Bone metastasis: pathogenesis and therapeutic implications. Clinical \& experimental metastasis 2007, 24, (8), 599-608.

47. Roodman, G. D., Mechanisms of bone metastasis. The New England journal of medicine 2004, 350, (16), 1655-64.

48. Keller ET, C. L., The biology of skeletal metastases. Kluwer Academic Publishers: Boston, 2004; Vol. 118.

49. O'Keefe, R. J.; Guise, T. A., Molecular mechanisms of bone metastasis and therapeutic implications. Clinical orthopaedics and related research 2003, (415 Suppl), S100-4.

50. Hirasawa, H.; Tanaka, S.; Sakai, A.; Tsutsui, M.; Shimokawa, H.; Miyata, H.; Moriwaki, S.; Niida, S.; Ito, M.; Nakamura, T., ApoE gene deficiency enhances the reduction of bone formation induced by a high-fat diet through the stimulation of p53-mediated apoptosis in osteoblastic cells. $J$ Bone Miner Res 2007, 22, (7), 1020-30.

51. Alford, A. I.; Terkhorn, S. P.; Reddy, A. B.; Hankenson, K. D., Thrombospondin-2 regulates matrix mineralization in MC3T3-E1 pre-osteoblasts. Bone 2010, 46, (2), 464-71. 
52. Tucker, R. P.; Adams, J. C.; Lawler, J., Thrombospondin-4 is expressed by early osteogenic tissues in the chick embryo. Dev Dyn 1995, 203, (4), 477-90.

53. Wilson, T. J.; Nannuru, K. C.; Futakuchi, M.; Sadanandam, A.; Singh, R. K., Cathepsin G enhances mammary tumor-induced osteolysis by generating soluble receptor activator of nuclear factor-kappaB ligand. Cancer Res 2008, 68, (14), 5803-11.

54. Thommesen, L.; Stunes, A. K.; Monjo, M.; Grosvik, K.; Tamburstuen, M. V.; Kjobli, E.; Lyngstadaas, S. P.; Reseland, J. E.; Syversen, U., Expression and regulation of resistin in osteoblasts and osteoclasts indicate a role in bone metabolism. J Cell Biochem 2006, 99, (3), 824-34.

55. Karlstrom, E.; Norgard, M.; Hultenby, K.; Somogyi-Ganss, E.; Sugars, R.; Andersson, G.; Wendel, M., Localization and expression of prothrombin in rodent osteoclasts and long bones. Calcif Tissue Int 2011, 88, (3), 179-88.

56. Schaefer, L.; lozzo, R. V., Biological functions of the small leucine-rich proteoglycans: from genetics to signal transduction. The Journal of biological chemistry 2008, 283, (31), 21305-9.

57. Waddington, R. J.; Roberts, H. C.; Sugars, R. V.; Schonherr, E., Differential roles for small leucine-rich proteoglycans in bone formation. Eur Cell Mater 2003, 6, 12-21; discussion 21.

58. Kalamajski, S.; Aspberg, A.; Lindblom, K.; Heinegard, D.; Oldberg, A., Asporin competes with decorin for collagen binding, binds calcium and promotes osteoblast collagen mineralization. Biochem J 2009, 423, (1), 53-9.

59. Raouf, A.; Ganss, B.; McMahon, C.; Vary, C.; Roughley, P. J.; Seth, A., Lumican is a major proteoglycan component of the bone matrix. Matrix Biol 2002, 21, (4), 361-7.

60. Hamajima, S.; Hiratsuka, K.; Kiyama-Kishikawa, M.; Tagawa, T.; Kawahara, M.; Ohta, M.; Sasahara, H.; Abiko, Y., Effect of low-level laser irradiation on osteoglycin gene expression in osteoblasts. Lasers Med Sci 2003, 18, (2), 78-82.

61. Wang, X.; Harimoto, K.; Xie, S.; Cheng, H.; Liu, J.; Wang, Z., Matrix protein biglycan induces osteoblast differentiation through extracellular signal-regulated kinase and Smad pathways. Biol Pharm Bull 2010, 33, (11), 1891-7.

62. Rucci, N.; Rufo, A.; Alamanou, M.; Capulli, M.; Del Fattore, A.; Ahrman, E.; Capece, D.; lansante, V.; Zazzeroni, F.; Alesse, E.; Heinegard, D.; Teti, A., The glycosaminoglycan-binding domain of PRELP acts as a cell type-specific NF-kappaB inhibitor that impairs osteoclastogenesis. $J$ Cell Biol 2009, 187, (5), 669-83.

63. Leygue, E.; Snell, L.; Dotzlaw, H.; Hole, K.; Hiller-Hitchcock, T.; Roughley, P. J.; Watson, P. H.; Murphy, L. C., Expression of lumican in human breast carcinoma. Cancer Res 1998, 58, (7), 1348-52.

64. Naito, Z., Role of the small leucine-rich proteoglycan (SLRP) family in pathological lesions and cancer cell growth. J Nippon Med Sch 2005, 72, (3), 137-45.

65. Seya, T.; Tanaka, N.; Shinji, S.; Yokoi, K.; Koizumi, M.; Teranishi, N.; Yamashita, K.; Tajiri, T.; Ishiwata, T.; Naito, Z., Lumican expression in advanced colorectal cancer with nodal metastasis correlates with poor prognosis. Oncol Rep 2006, 16, (6), 1225-30.

66. Zeltz, C.; Brezillon, S.; Kapyla, J.; Eble, J. A.; Bobichon, H.; Terryn, C.; Perreau, C.; Franz, C. M.; Heino, J.; Maquart, F. X.; Wegrowski, Y., Lumican inhibits cell migration through alpha2beta1 integrin. Exp Cell Res 2010, 316, (17), 2922-31.

67. Brezillon, S.; Radwanska, A.; Zeltz, C.; Malkowski, A.; Ploton, D.; Bobichon, H.; Perreau, C.; Malicka-Blaszkiewicz, M.; Maquart, F. X.; Wegrowski, Y., Lumican core protein inhibits melanoma cell migration via alterations of focal adhesion complexes. Cancer Lett 2009, 283, (1), 92-100.

68. Iozzo, R. V.; Schaefer, L., Proteoglycans in health and disease: novel regulatory signaling mechanisms evoked by the small leucine-rich proteoglycans. FEBS J 2010, 277, (19), 3864-75.

69. Araki, K.; Wakabayashi, H.; Shintani, K.; Morikawa, J.; Matsumine, A.; Kusuzaki, K.; Sudo, A.; Uchida, A., Decorin suppresses bone metastasis in a breast cancer cell line. Oncology 2009, 77, (2), 92-9. 
70. Yamada, S.; Tomoeda, M.; Ozawa, Y.; Yoneda, S.; Terashima, Y.; Ikezawa, K.; Ikegawa, S.; Saito, M.; Toyosawa, S.; Murakami, S., PLAP-1/asporin, a novel negative regulator of periodontal ligament mineralization. J Biol Chem 2007, 282, (32), 23070-80.

71. Ikegawa, S., Expression, regulation and function of asporin, a susceptibility gene in common bone and joint diseases. Curr Med Chem 2008, 15, (7), 724-8.

72. Nakajima, M.; Kizawa, H.; Saitoh, M.; Kou, I.; Miyazono, K.; Ikegawa, S., Mechanisms for asporin function and regulation in articular cartilage. J Biol Chem 2007, 282, (44), 32185-92.

73. Turashvili, G.; Bouchal, J.; Baumforth, K.; Wei, W.; Dziechciarkova, M.; Ehrmann, J.; Klein, J.; Fridman, E.; Skarda, J.; Srovnal, J.; Hajduch, M.; Murray, P.; Kolar, Z., Novel markers for differentiation of lobular and ductal invasive breast carcinomas by laser microdissection and microarray analysis. BMC Cancer 2007, 7, 55.

74. Peyruchaud, O.; Winding, B.; Pecheur, I.; Serre, C. M.; Delmas, P.; Clezardin, P., Early detection of bone metastases in a murine model using fluorescent human breast cancer cells: application to the use of the bisphosphonate zoledronic acid in the treatment of osteolytic lesions. $J$ Bone Miner Res 2001, 16, (11), 2027-34.

75. Pecheur, I.; Peyruchaud, O.; Serre, C. M.; Guglielmi, J.; Voland, C.; Bourre, F.; Margue, C.; Cohen-Solal, M.; Buffet, A.; Kieffer, N.; Clezardin, P., Integrin alpha(v)beta3 expression confers on tumor cells a greater propensity to metastasize to bone. FASEB J 2002, 16, (10), 1266-8.

76. Le Gall, C.; Bellahcene, A.; Bonnelye, E.; Gasser, J. A.; Castronovo, V.; Green, J.; Zimmermann, J.; Clezardin, P., A cathepsin $\mathrm{K}$ inhibitor reduces breast cancer induced osteolysis and skeletal tumor burden. Cancer Res 2007, 67, (20), 9894-902.

77. Futterer, A.; Kruppa, G.; Kramer, B.; Lemke, H.; Kronke, M., Molecular cloning and characterization of human kinectin. Mol Biol Cell 1995, 6, (2), 161-70.

78. Sjoblom, T.; Jones, S.; Wood, L. D.; Parsons, D. W.; Lin, J.; Barber, T. D.; Mandelker, D.; Leary, R. J.; Ptak, J.; Silliman, N.; Szabo, S.; Buckhaults, P.; Farrell, C.; Meeh, P.; Markowitz, S. D.; Willis, J.; Dawson, D.; Willson, J. K.; Gazdar, A. F.; Hartigan, J.; Wu, L.; Liu, C.; Parmigiani, G.; Park, B. H.; Bachman, K. E.; Papadopoulos, N.; Vogelstein, B.; Kinzler, K. W.; Velculescu, V. E., The consensus coding sequences of human breast and colorectal cancers. Science 2006, 314, (5797), 268-74.

79. Wang, H. C.; Su, Y. R.; Han, K. J.; Pang, X. W.; Peng, J. R.; Liang, B.; Wang, S.; Chen, W. F., Multiple variants and a differential splicing pattern of kinectin in human hepatocellular carcinoma. Biochem Cell Biol 2004, 82, (2), 321-7.

80. Babeto, E.; Conceicao, A. L.; Valsechi, M. C.; Peitl Junior, P.; de Campos Zuccari, D. A.; de Lima, L. G.; Bonilha, J. L.; de Freitas Calmon, M.; Cordeiro, J. A.; Rahal, P., Differentially expressed genes in giant cell tumor of bone. Virchows Arch 2011, 458, (4), 467-76.

81. Sutton, C. W.; Rustogi, N.; Gurkan, C.; Scally, A.; Loizidou, M. A.; Hadjisavvas, A.; Kyriacou, K., Quantitative proteomic profiling of matched normal and tumor breast tissues. Journal of proteome research 2010, 9, (8), 3891-902.

82. Hergeth, S. P.; Aicher, W. K.; Essl, M.; Schreiber, T. D.; Sasaki, T.; Klein, G., Characterization and functional analysis of osteoblast-derived fibulins in the human hematopoietic stem cell niche. Exp Hematol 2008, 36, (8), 1022-34.

83. Akiyama, T.; Dass, C. R.; Shinoda, Y.; Kawano, H.; Tanaka, S.; Choong, P. F., PEDF regulates osteoclasts via osteoprotegerin and RANKL. Biochem Biophys Res Commun 2010, 391, (1), 789-94.

84. Litvin, J.; Selim, A. H.; Montgomery, M. O.; Lehmann, K.; Rico, M. C.; Devlin, H.; Bednarik, D. P.; Safadi, F. F., Expression and function of periostin-isoforms in bone. J Cell Biochem 2004, 92, (5), 1044-61.

85. Iba, K.; Chiba, H.; Yamashita, T.; Ishii, S.; Sawada, N., Phase-independent inhibition by retinoic acid of mineralization correlated with loss of tetranectin expression in a human osteoblastic cell line. Cell Struct Funct 2001, 26, (4), 227-33. 
86. Kanakis, I.; Nikolaou, M.; Pectasides, D.; Kiamouris, C.; Karamanos, N. K., Determination and biological relevance of serum cross-linked type I collagen $\mathrm{N}$-telopeptide and bone-specific alkaline phosphatase in breast metastatic cancer. J Pharm Biomed Anal 2004, 34, (4), 827-32. 


\section{SUMMARY}
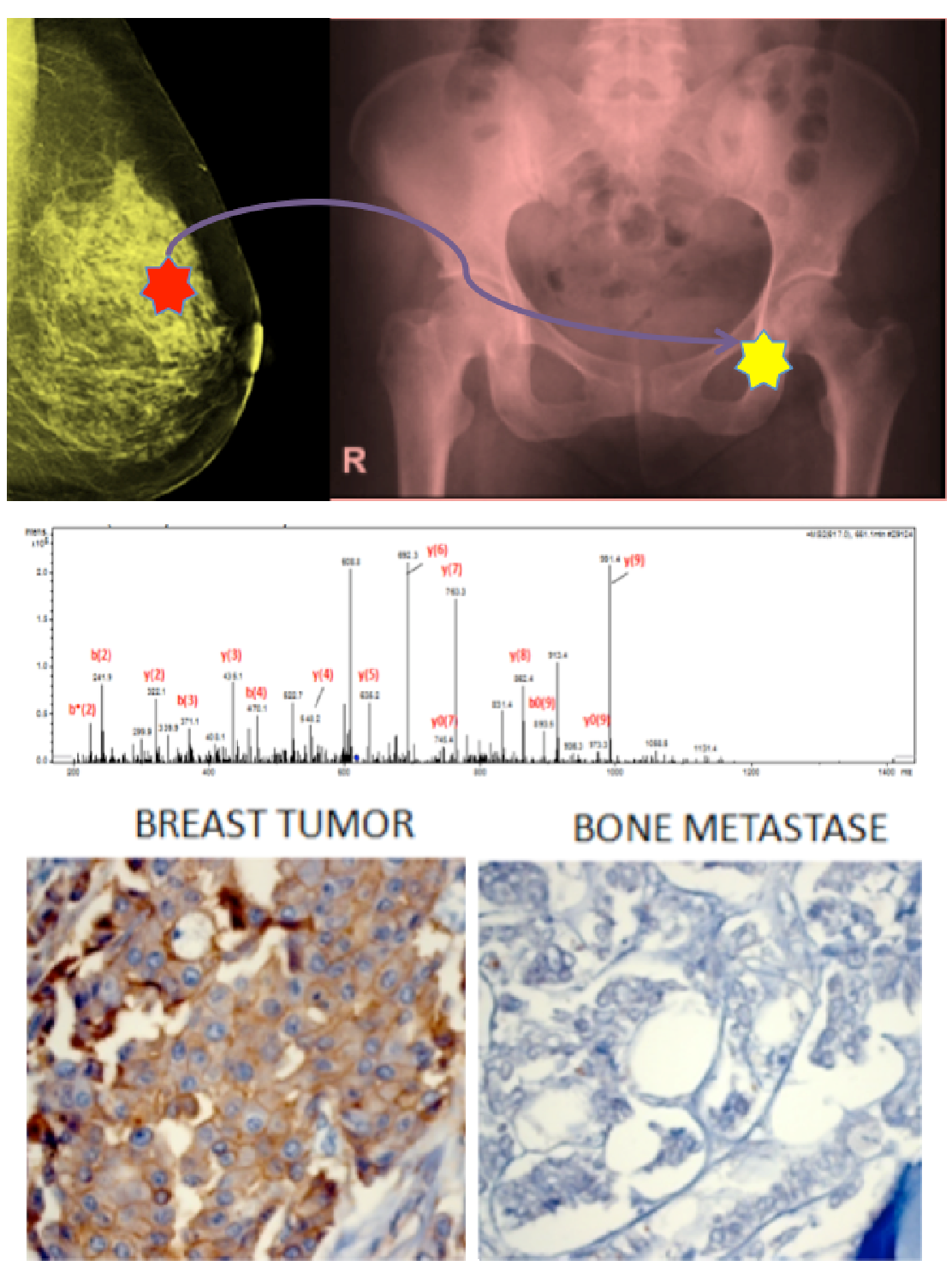

Breast tumor becomes incurable when it metastasizes to bone. Unfortunately, the underlying mechanism and associated proteins are yet insufficiently understood/explored. Starting from a unique clinical material consisting of a breast tumor and corresponding bone metastasis, sampled from the same patient at the same time, the current study explores the membrane and extracellular proteome. The described results create grounds for future functional investigations and are a contribution towards better understanding of how cancer cells disseminate to the skeleton. 